\title{
Multi-proxy records of Mesolithic activity in the Lubuskie Lakeland (western Poland)
}

\author{
Iwona Sobkowiak-Tabaka ${ }^{1}$ D $\cdot$ Dominik Pawłowski ${ }^{2} \cdot$ Krystyna Milecka $^{3} \cdot$ Lucy Kubiak-Martens $^{4} \cdot$ Robert Kostecki $^{3}$. \\ Beata Janczak-Kostecka ${ }^{3} \cdot$ Tomasz Goslar $^{5,6} \cdot$ Magdalena Ratajczak-Szczerba ${ }^{3}$
}

Received: 22 April 2019 / Accepted: 27 September 2019 / Published online: 14 November 2019

(c) The Author(s) 2019

\begin{abstract}
The results of high-resolution records of pollen, plant macroremains and charred plant particles, diatoms, Cladocera and geochemistry from a ${ }^{14} \mathrm{C}$-dated core, and geomorphological studies enabled the reconstruction of landscape development at a site in western Poland which was occupied by Mesolithic hunter-gatherer groups. Special attention was paid to the evidence of human activities recorded in the sediments of the palaeolake located next to the archaeological site. The presence of pollen types from communities characteristic of openings in the forest, macroscopic/microscopic charcoal, and charred particles of herbaceous plants (mostly from between 5500 and 4600 BC, with clearly visible maxima ca 5300, 4900 and 4700 BC) evidence the changes related to these various kinds of activities. These analyses allowed us to reconstruct the fire events at and around the site as well as to consider whether they originated from natural or human induced fires. The increase in the biogenic sediments of elements such as $\mathrm{Na}, \mathrm{K}$ and $\mathrm{Mg}$ indicate an intensive erosion of mineral soil between 5100 and $4600 \mathrm{BC}$, mirroring human activity in the vicinity of the Kopanica site. In addition, Cladocera analysis permitted a detailed recognition of palaeolake eutrophication ca 7200-4600 BC, also eutrophication induced by human impact between 5100 and 4600 BC.
\end{abstract}

Keywords Palaeoenvironment $\cdot$ Multi-proxy analyses $\cdot$ Hunter-gatherers $\cdot$ Human impact $\cdot$ Holocene $\cdot$ Late Mesolithic

Communicated by C. A. H. E. Jensen.

Electronic supplementary material The online version of this article (https://doi.org/10.1007/s00334-019-00752-3) contains supplementary material, which is available to authorized users.

Iwona Sobkowiak-Tabaka

iwona.sobkowiak@iaepan.poznan.pl

1 Institute of Archaeology and Ethnology, Polish Academy of Sciences, Rubież 46, 61-612 Poznań, Poland

2 Institute of Geology, Faculty of Geographical and Geological Sciences, Adam Mickiewicz University, B. Krygowskiego 12, 61-680 Poznań, Poland

3 Institute of Geoecology and Geoinformation, Faculty of Geographical and Geological Sciences, Adam Mickiewicz University, B. Krygowskiego 10, 61-680 Poznań, Poland

4 Biological Archaeology \& Environmental Reconstruction, BIAX Consult, Symon Spiersweg 7 D2, 506 RZ Zaandam, The Netherlands

5 Faculty of Physics, Adam Mickiewicz University, Umultowska 85, 61-614 Poznań, Poland

6 Poznań Radiocarbon Laboratory, Poznań Park of Science and Technology, Rubież 46, 61-612 Poznań, Poland

\section{Introduction}

The reconstruction of the palaeoenvironment is an important part of the studies of Late Palaeolithic and Mesolithic settlements. Due to the specific character of the hunter-gatherer way of living, environmental conditions were significant factors in choosing camp locations and hunting strategies, in selecting equipment or in group reactions to climate changes. Equally important are multi-proxy analyses of the evidence of human impact on the landscape (e.g., Innes et al. 2013; Mortensen et al. 2014a, b; Taylor et al. 2018).

Ten AMS ${ }^{14} \mathrm{C}$ dates made on plant macroremains produced data for the detailed chronology of the biogenic sediments and human occupation of the Kopanica 29 site. Palaeolimnological approaches provided important supporting information about human impact on the environment around its former settlements (Szeroczyńska 2002; Kittel et al. 2014). Subfossil remains of Cladocera, a group of microcrustaceans, were preserved in the sediments. These aquatic invertebrates are widely used to describe climatic changes (e.g., Nevalainen et al. 2012; Pawłowski 2017), changes in lake level (e.g., Nevalainen 2011) and to reveal the trophic 
status of lakes including human-environment relationships (Tóth et al. 2019).

The multi-proxy study presented here employs palaeobiological, geochemical, archaeological and radiometric data to investigate the Mesolithic hunter-gatherer groups' impact on the landscape of this part of central Europe.

\section{Regional settings}

Kopanica is located in the western part of Poland, between two local physical geographic regions-the Zbąszyń Furrow and Kargowa Basin (Fig. 1a), and is situated within a former subglacial channel (tunnel valley) of the Zbąszyń Lakes (Fig. 1b) along the Northern Canal of the Obra River (Fig. 1c). Nowadays, water in the Obra River flows to the north, to the Warta River valley. During the Late Glacial period it flowed to the south, to the Warsaw-Berlin icemarginal valley. The Northern Obra Canal, and the second canal of the Obra River - the so-called Gniła Obra Riverare located to the west of Kopanica, and carved a system of elevations during the Poznań phase of the last Scandinavian ice sheet (the Weichselian Glaciation). Today, the Zbąszyń Lakes tunnel valley is shallow and filled by several lakes among which Zbąszyń Lake is the biggest. Alluvial silts, sands and gravels, as well as peats and gyttjas, are the main deposits covering the surface of the valley floor of the North Obra Canal. General descriptions of the geological and geomorphological setting of the study site have been presented by Krygowski (1972) and Multan (2003).

Soils typical of a subboreal wet zone are observed at the studied area (Bednarek and Prusinkiewicz 1997). They are mainly represented by podzols, developed from sandy, fluvioglacial deposits including sandur deposits after the last glaciation. The intrazonal soils are represented by fluvisols in the Obra valley (Bednarek and Prusinkiewicz 1997).

\section{Archaeological data}

The archaeological site is located on the eastern edge of the Zbąszyń Lakes tunnel valley (Figs. 1c, 2), at the highest point (ca $55 \mathrm{~m}$ a.s.l.) and on a slope of the highest fluvial terrace of the Obra River. The area of the Mesolithic camp at Kopanica covers ca $500 \mathrm{~m}^{2}$. Trenches were set mainly on the fluvial terrace and one ditch was dug out in the flood plain (Fig. 3a). The fluvial terrace was built of silty and, in some parts, of massive sands. In the western part of the site, underneath the sands, thick and very diversified layers of peat were recorded (Fig. 3b). During four archaeological seasons ca 12,000 flint artefacts, several tiny, heavily burnt animal bones and a lump of amber were recorded. Artefacts found in all of the trenches were distributed evenly and did not form any distinct concentration. A fact worth highlighting is that ca $35 \%$ of the flint artefacts were heavily burnt. In the central part of the investigated area, remains of a shallow
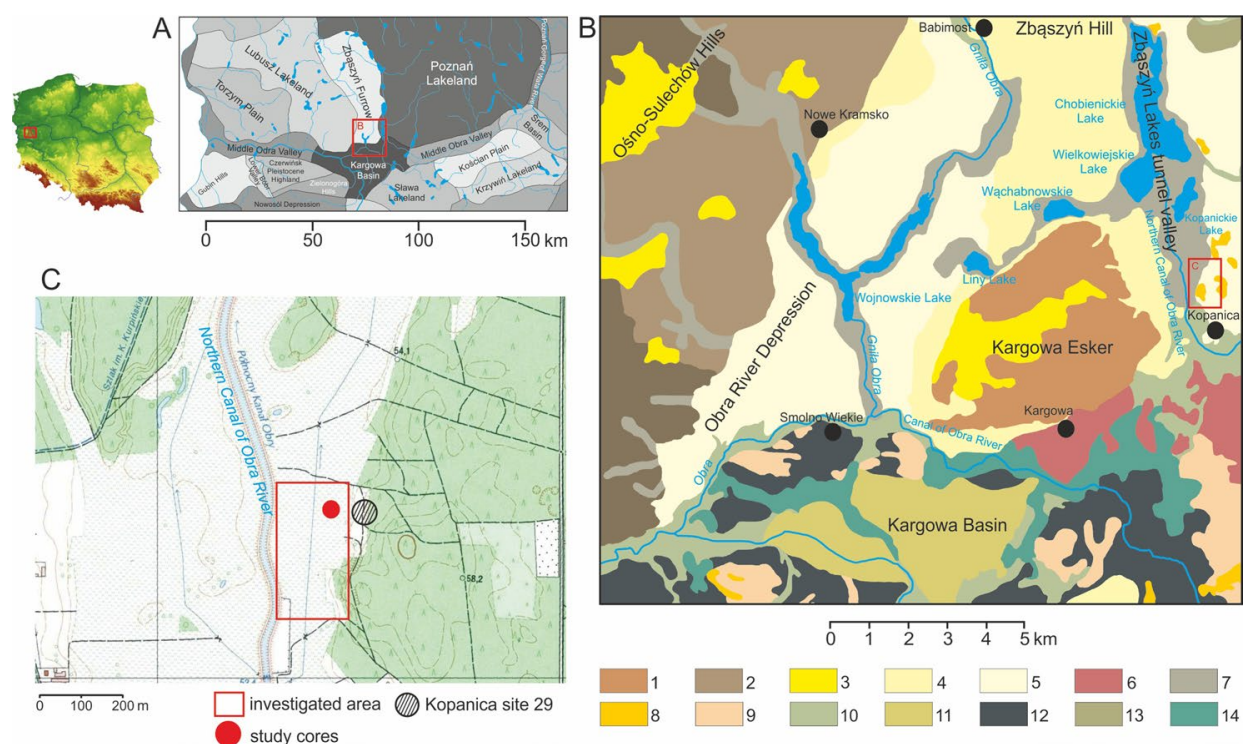

Fig. 1 Location, geomorphological and hypsometric characteristics of the Kopanica site and fragment of the Northern Canal of the Obra River valley under investigation. a The map with a physiographic division; b Geomorphological map acc. to Multan (2003): 1-flat moraine plateau, 2-undulated and hummocky moraine plateau, 3-I level of moraine plateau (outwash plain), 4-II level of moraine plateau (outwash plain), 5-III level of moraine plateau (outwash plain), 6 - outwash terrace, 7-troughs used by rivers and partly transformed

by them, 8-dunes, 9-aeolian sand covers, 10-bottoms of rivers valleys, 11-accumulation terrace, 12-alluvian fan, 13-denudation plains, 14-biogenic matter accumulation plain (peat plains); c Hypsometric map of the Northern Canal of the Obra River, with the location of the investigated area. The study cores (K17A and K17B) are placed next to one another, and appropriate symbols used in the maps overlap each other 


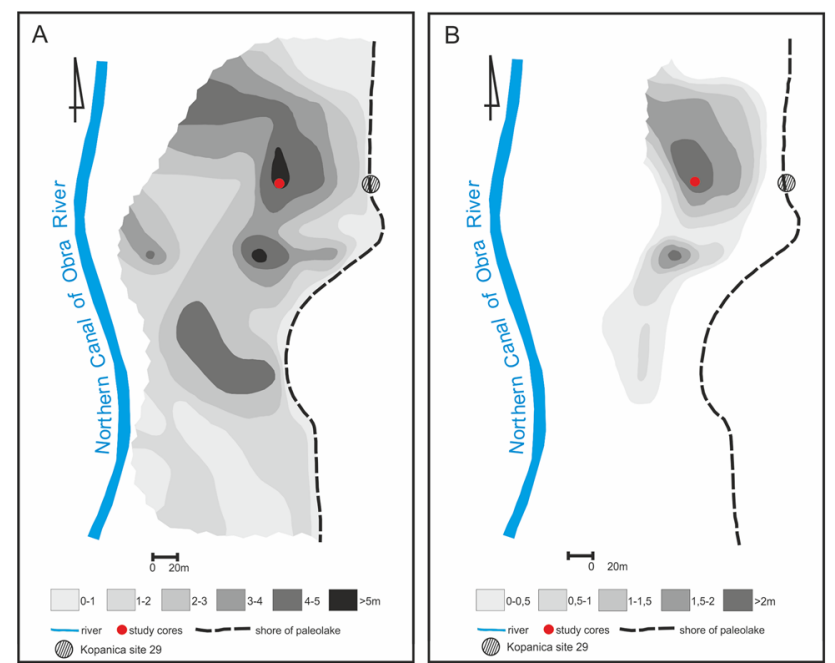

Fig. 2 Maps of the investigated fragment of the valley of the Northern Canal of the Obra River showing the distribution of biogenic sediments based on coring measurements (a), and thickness of gyttja (b). Thicknesses were stained in shades of grey. The cores K17A and K17B are placed next to one another, and appropriate symbols used in the maps overlap each other

pit-house, containing 77 flint artefacts and a fragment of burnt bone, were registered. The feature was $3.6 \mathrm{~m}$ in diameter. Twenty postholes, spaced at regular intervals and forming roughly two outer rings, were located around it (Fig. 3a; Bobrowski and Sobkowiak-Tabaka 2016).

Almost all identified raw material was local, a poor quality non-pebble variety of erratic Baltic flint. Some artefacts were made of fine-grained quartzite and one trapeze was made of chocolate flint. People occupying the site used mostly small nodules of local raw material or chunks from cracked lumps, usually 50-60 $\mathrm{mm}$ in diameter.

Beside cores, flake and blade blanks, and debitage, the excavations produced typical Mesolithic tools, such as endscrapers, scrapers, macrolithic tools (one pick, two flake adzes), and insets - triangles and trapezes. The triangles and trapezes are commonly viewed as chronological markers for Late Mesolithic assemblages (after ca 6000 вс-Kozłowski and Kozłowski 1977).

Neither the location of the camp (on loose ground causing vertical and horizontal movement of artefacts), nor the uneven distributions of artefacts, nor the long [continuous?] occurrence of insets, even when viewed as chronological markers, allow us to distinguish these episodes by archaeological methods.

Moreover, surveys and excavations which have been carried out since the 1930s in this region, known as Wojnowo Region, show that the terraces of the Obra River valley are carpeted by thousands of lithic artefacts (Kobusiewicz 2016), indicating repeated settlement events in the Late Glacial and the Early Holocene. This phenomenon

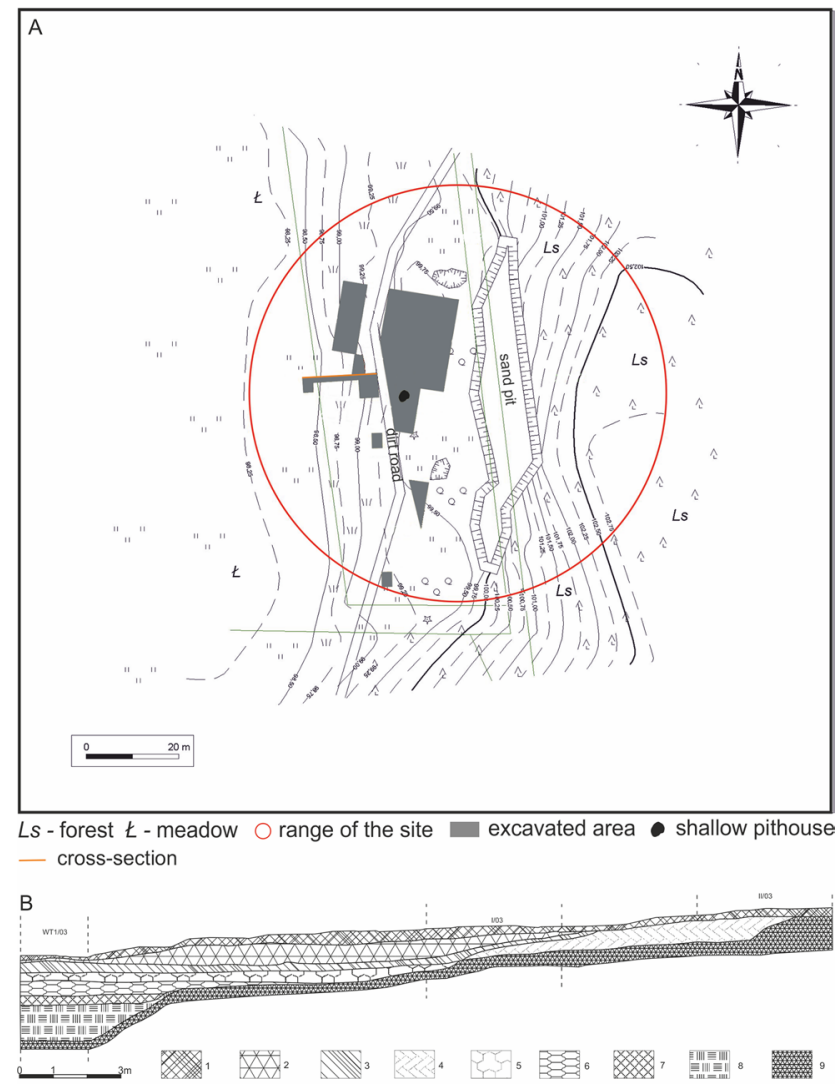

Fig. 3 a Location of the trenches at the site against the topographic map; b Cross-section of the trenches. 1-humus, 2-pale yellow fine-grained clayey sand, 3-light brown weakly decomposed peat, 4 - grey fine-grained sand mixed with humus, 5-dark brown highly decomposed peat, 6-yellowish weakly decomposed peat, 7-black highly decomposed peat, 8-dark brown well-decomposed peat, 9-light grey fine-grained gravel (after Bobrowski and SobkowiakTabaka 2016 with modifications)

probably occurred due to favourable environmental conditions, especially a unique hydrographical system of lakes connecting the Obra River and the Obrzyca River valleys from the south and the Gniła Obra River from the north. These valleys may have been very important communication arteries and the source of fresh water and fishing (Hildebrandt-Radke 2016). Such regions, called persistent places, are commonly known from different parts of the world and various times (i.e., Schlanger 1992; Vanmontfort et al. 2010; Turner et al. 2013; Sobkowiak-Tabaka et al. 2018).

The off-site analysis of materials also allowed us to distinguish several artefacts related to the Late Palaeolithic, i.e., a shouldered point - a typical projectile for the Hamburgian societies which recolonized the North European Plain after the Weichselian Glaciation, and tanged points, characteristic of societies existing in the Younger Dryas and the beginning of the Holocene. These artefacts attest to a short-time stay or penetration of the vicinity of the site rather than to the 


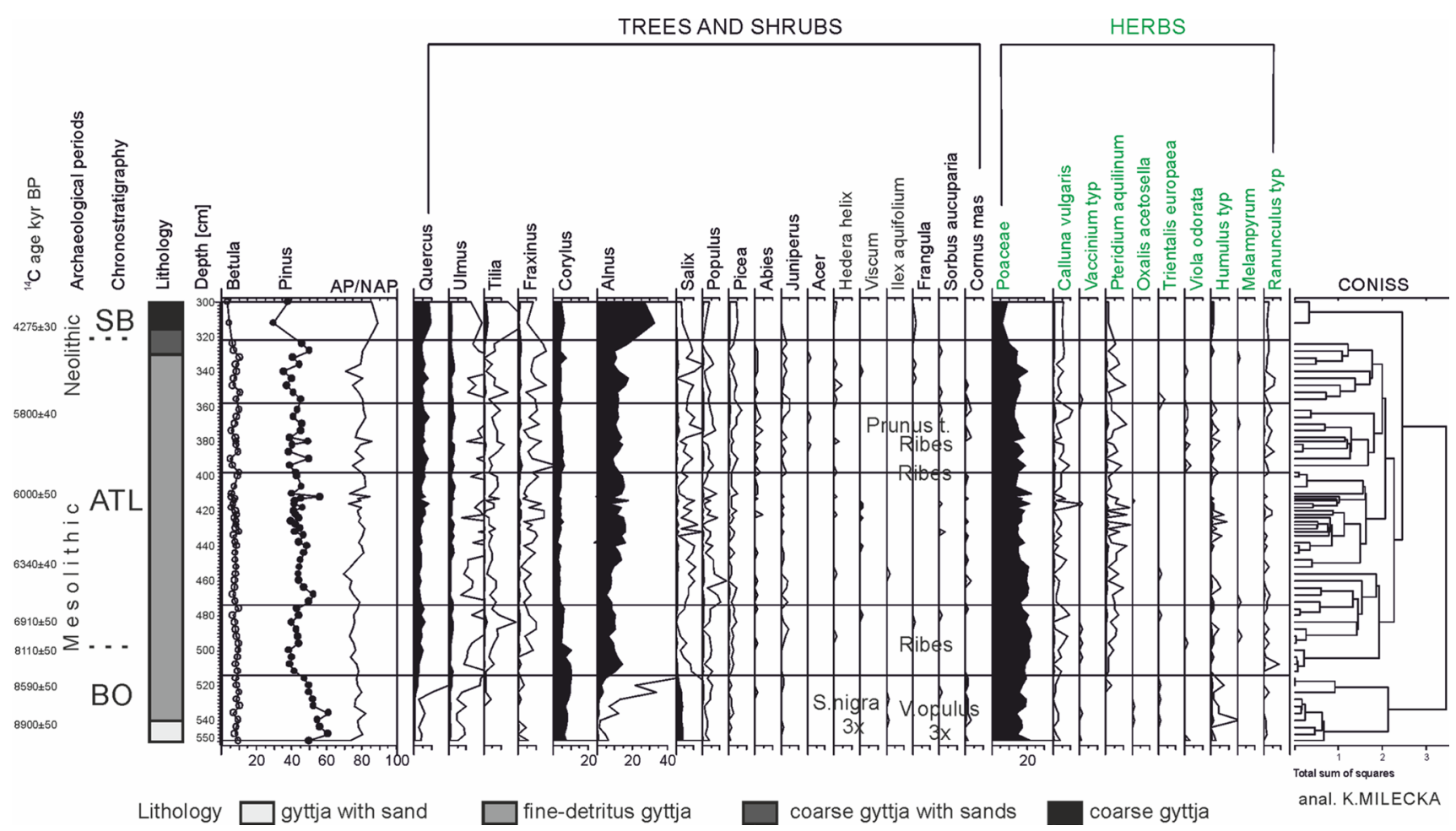

Fig. 4 Percentage pollen diagram and chronostratigraphic division of the Kopanica site. Coniss constrained incremental sums of squares cluster, NPPs non-pollen palynomorphs

permanent settlement of Late Palaeolithic societies, known from many sites located nearby (Kobusiewicz 2016).

\section{Materials and methods}

\section{Fieldwork}

Geological and geomorphological investigations covered the south-eastern fragment of the Zbąszyń Lakes tunnel valley (Figs. 1,2) in the vicinity of the archaeological sites. A series of assessment drillings were done using a manual Eijkelkamp type sampler. In total, 58 profiles through limnic (gyttja) and telmatic (peat) sediments along 12 profile lines to the north of Kopanica were collected. The map of biogenic sediments, including gyttja deposits, was produced using the method of graphic interpolation (Fig. 2). Sediment cores for palaeoenvironmental and geochemical studies were collected (using a manual Piston corer) where the thickest organic deposits were found (Fig. 2). Two parallel cores, K17A and K17B, were taken to ensure sufficient overlap between the parts of the cores. The cores were approximately $0.5 \mathrm{~m}$ apart. In the laboratory, the cores were sliced into $1 \mathrm{~cm}$ interval sections for further investigations and stored in a cold room.

\section{Palaeobiological data}

\section{Pollen}

Samples for pollen analysis were taken every 2 or $4 \mathrm{~cm}$. They were prepared according to standard procedures (Berglund and Ralska-Jasiewiczowa 1986), using acetolysis for $3 \mathrm{~min}$. Before the preparation of pollen slides, samples were stained with safranine. Every pollen spectrum was counted to at least 500 pollen grains of trees and shrubs (AP). Identification and taxonomy followed Beug (2004) and the collection of the Department of Biogeography and Palaeoecology AMU in Poznań. The sum of AP and herbs (NAP) formed the base for percentage calculations (calculation sum). Aquatics, telmatophytes and selected non-pollen palynomorphs (NPPs) were counted as well; however, these were not included into the calculation sum. Pollen diagrams were prepared in Tilia and Tilia Graph programs (Grimm 1992) and improved in CorelDraw (Fig. 4).

\section{Plant macroremains}

Samples for plant macroremains analysis were taken every 1 or $2 \mathrm{~cm}$. Plant macrofossil samples were washed through a sieve with a mesh size of $0.25 \mathrm{~mm}$ at the BIAX Consult laboratory. The plant macrofossils captured on the sieve 


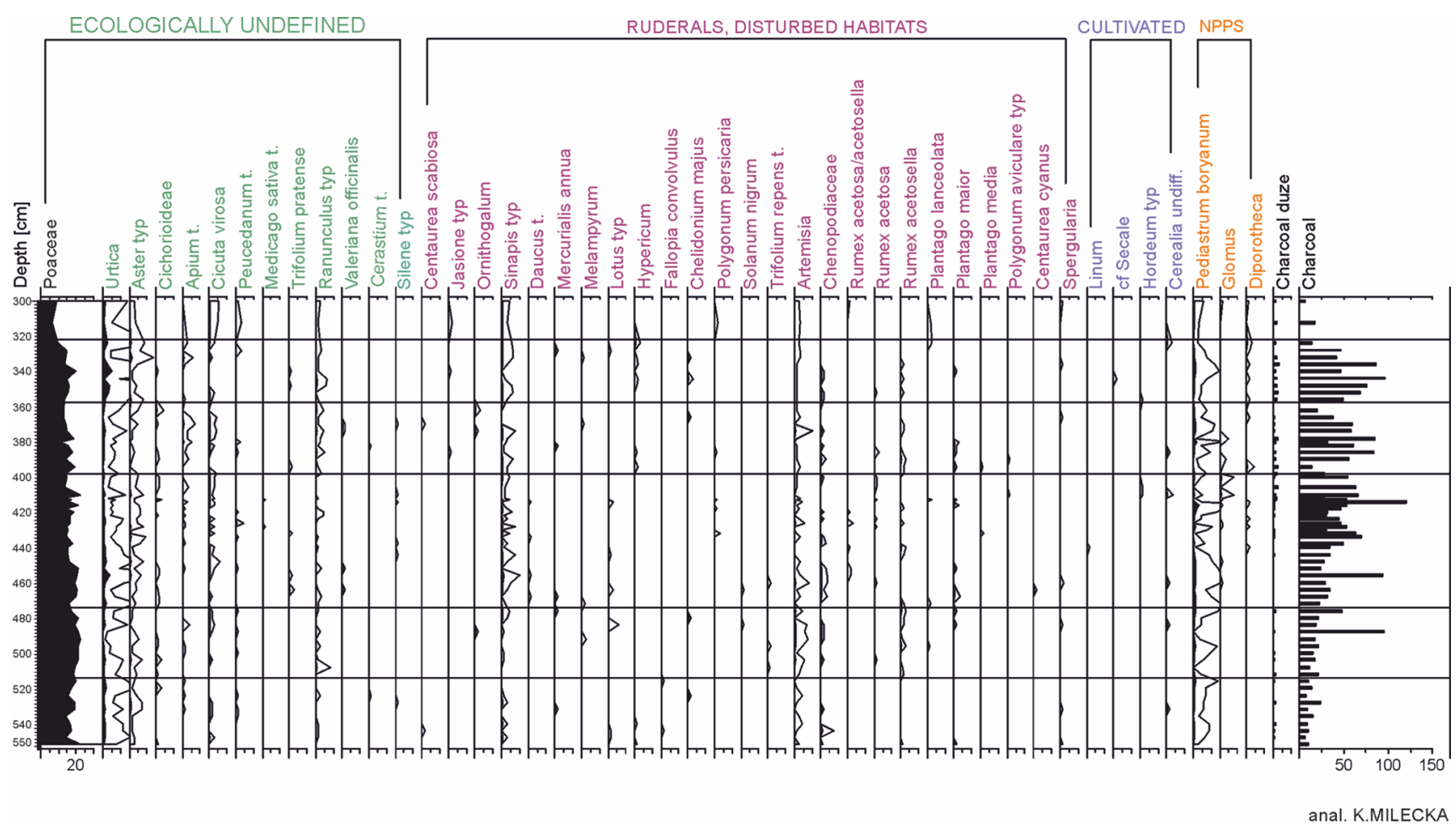

Fig. 4 (continued)

were subsequently identified, using a Leica-binocular incident light microscope at magnifications of $\times 6$ to $\times 50$. During analysis, special attention was paid to the occurrences of charcoal and other charred plant remains throughout the studied assemblages, which would possibly indicate human presence in the studied area. The selection of plant material for AMS radiocarbon analysis was carried out on both sediment cores, K17A and K17B. In Table 1, the results of AMS radiocarbon dating are given for the site. The results of plant macrofossil analysis are presented as a Tilia Graph histogram in Fig. 5.

\section{Diatoms}

Samples for diatom analysis were taken every 2 or $4 \mathrm{~cm}$. The standard methods (Battarbee 1986) were used for the preparation of diatom samples. Between 300 and 500 diatom valves were counted in each sample in order to estimate the percentage abundances of particular taxa (Schrader and Gersonde 1978). The diatom species were divided into groups according to their biotope requirements; planktonic, periphytonic and benthic groups were distinguished (Round 1981). Diatoms were grouped with respect to their $\mathrm{pH}$ classification requirements according to Hustedt (1939), trophic conditions according to Naumann (1932), and saprobity according to Kolkwitz and Marsson (1908).
The identification and ecological information were based on studies by Denys (1991), Krammer and Lange-Bertalot (1986, 1988, 1991a, b) and Krammer (2002). The percentage content of all ecological groups was estimated in each sample. Local diatom assemblage zones (LDAZs) were distinguished based on differences in the species composition, the relative frequencies of diatom taxa, and the prevalent ecological and habitat groups.

\section{Cladocera}

Each $1 \mathrm{~cm}^{3}$ sample of deposit was processed according to the standard procedure (Frey 1986). A minimum of 200 cladoceran remains per sample was identified. The taxonomy of cladoceran remains in this paper follows that presented by Szeroczyńska and Sarmaja-Korjonen (2007). The ecological preferences of cladoceran taxa were determined on the basis of the published key after Bjerring et al. (2009). A stratigraphically constrained cluster analysis (CONISS) was applied to distinguish cladoceran zones.

\section{Geochemical data}

Samples for geochemical analysis were taken every 2 or $4 \mathrm{~cm}$. Geochemical analyses were conducted to determine organic matter, calcium carbonate, contents of terrigenous $\left(\mathrm{Si}_{\text {ter }}\right)$ and biogenic silica $\left(\mathrm{Si}_{\text {biog }}\right)$ and the metals sodium 
Table 1 Radiocarbon dated samples of the Kopanica cores K17A-K17B

\begin{tabular}{|c|c|c|c|c|}
\hline Depth $(\mathrm{cm})$ & Lab. code & Dated plant remains & ${ }^{14} \mathrm{C}$ age (years вP) & cal age $(\mathrm{BC})^{*}$ \\
\hline $313-314$ & Poz-104686 & $\begin{array}{l}\text { Alnus glutinosa-catkin } 1 \mathrm{frg} \text {, fruit } 1 \times \text { (un-charred); Phragmites australis-culm (with } \\
\text { epidermis) } 3 \text { frg (charred) }\end{array}$ & $4,275 \pm 30$ & $3,003-2,779$ \\
\hline $363-364$ & Poz-104687 & A. glutinosa-fruit $1 \times$; Quercus-bud scale $1 \times$; small twigs 3 frg (un-charred) & $5,800 \pm 40$ & $4,767-4,544$ \\
\hline $409-410$ & Poz-104689 & $\begin{array}{l}\text { A. glutinosa-fruit } 3 \times \text {; Urtica dioica } 1 \times \text { (un-charred); Ph. australis-culm (with } \\
\text { epidermis) } 3 \text { frg (charred) }\end{array}$ & $6,000 \pm 50$ & $5,026-4,771$ \\
\hline $424-425$ & Poz-104690 & $\begin{array}{l}\text { A. glutinosa-fruit } 2 \times \text {; Stachys palustris } 1 \mathrm{frg} \text {; Valeriana officinalis } 1 \times(\text { un-charred); } \\
\text { Ph. australis-culm (with epidermis) } 8 \mathrm{frg}\end{array}$ & $6,010 \pm 50$ & $5,037-4,784$ \\
\hline $449-450$ & Poz-104691 & $\begin{array}{l}\text { A. glutinosa-fruit } 2 \times \text {; Betula cf. pendula-fruit } 1 \times \text {; U. dioica } 2 \times \text {; Persicaria minor/ } \\
\text { mitis } 1 \times \text {; Carex } 1 \mathrm{frg} \text {; Stellaria cf. neglecta } 1 \mathrm{frg}(\text { un-charred); Ph. australis-culm } \\
\text { (with epidermis) } 8 \mathrm{frg}\end{array}$ & $6,340 \pm 40$ & $5,465-5220$ \\
\hline $460-461$ & Poz-108927 & $\begin{array}{l}\text { Betula (tree birch)-fruit } 2 \times ; \text {. glutinosa-fruit } 2 \times \text {; } \text {. dioica } 1 \times \text {; St. palus- } \\
\text { tris } 1 \times \text {; Mentha aquatica } 1 \times ; \text { Lycopus europaeus } 1 \times \text {, herbaceous stem/leaf } \\
\text { frgs. }+ \text { (charred) }\end{array}$ & $6,240 \pm 40$ & $5,311-5,066$ \\
\hline $480-486$ & Poz-108928 & $\begin{array}{l}\text { A. glutinosa-fruit } 2 \times ; \text { L. europaeus } 4 \times ; \text { U. dioica } 1 \times \text {; Carex } 3 \text { stig } 1 \mathrm{frg} \text {; herbaceous } \\
\text { stem/leaf frgs. }+(\text { charred })\end{array}$ & $6,910 \pm 50$ & $5,968-5,708$ \\
\hline $498-503$ & Poz-108929 & $\begin{array}{l}\text { Betula-fruit } 3 \times \text {; Pinus sylvestris-needle (charred) } 1 \text { frg., -bud scale } 1 \times ; \text { A. gluti- } \\
\text { nosa-fruit } 3 \times ; \text { Rumex hydrolapathum } 1 \times ; \text { L. europaeus } 1 \times \text {; herbaceous stem/ } \\
\text { leaf frgs. }+ \text { (charred) }\end{array}$ & $8,110 \pm 50$ & $7,308-6,846$ \\
\hline $520-524$ & Poz-108930 & $\begin{array}{l}\text { Betula (tree birch)-fruit } 5 \times ; \text { P. sylvestris-bud scale } 4 \times \text {, -seed wing } 2 \mathrm{frg} . ; M . \\
\text { aquatica } 3 \times ; \text { Oenanthe aquatica } 1 \mathrm{frg} ; R \text {. hydrolapathum } 1 \times \text {; herbaceous stem/ } \\
\text { leaf frgs. }+ \text { (charred) }\end{array}$ & $8,590 \pm 50$ & $7,722-7,541$ \\
\hline $540-543$ & Poz-108925 & $\begin{array}{l}\text { Betula (tree birch)-fruit } 16 \times ; \text { P. sylvestris-bud scale } 4 \times ; \text { L. europaeus } 3 \times \text {; Carex } \\
\text { rostrata } 1 \mathrm{frg} ; \text { M. aquatica } 2 \times ; \text { Eupatorium cannabinum } 2 \times \text {; U. dioica } 1 \times \text {; her- } \\
\text { baceous stem/leaf frgs. }+ \text { (charred) }\end{array}$ & $8,900 \pm 50$ & $8,248-7,842$ \\
\hline $570-572$ & Poz-108926 & $\begin{array}{l}\text { P. sylvestris-seed } 1 \times \text {, -needle } 3 \text { frg, -bud scales } 2 \times \text {; L. europaeus } 1 \times \text {; herbaceous } \\
\text { stem/leaf frgs }+(\text { charred })\end{array}$ & $9,350 \pm 50$ & $8,754-8,471$ \\
\hline
\end{tabular}

Ages have been calibrated (IntCal13; 95.4\% probability) using OxCal 4.3

*The AMS ${ }^{14} \mathrm{C}$ dates were calibrated using the online calibration program provided by C. Bronk Ramsey, OxCal 2019

$(\mathrm{Na})$, potassium $(\mathrm{K})$, magnesium $(\mathrm{Mg})$, calcium $(\mathrm{Ca})$, iron $(\mathrm{Fe})$ and manganese $(\mathrm{Mn})$. Loss on ignition (LOI) of organic matter content was the result of the combustion of dried samples at $550{ }^{\circ} \mathrm{C}$ while the calcium carbonate content was the result of combustion at $950{ }^{\circ} \mathrm{C}$ (Heiri et al. 2001). The total silica content was measured as the result of digestion in aqua regia in a water bath, while terrigenous silica content was measured after the dissolution of biogenic silica in a solution of sodium hydroxide. The metal contents were determined in digested liquid samples using flame atomic absorption spectrometry. The core was subdivided into local geochemical units based on the constrained hierarchical clustering algorithm implemented in the $\mathrm{R}$ package rioja (Juggins 2017). The number of significant units was determined by the broken-stick algorithm, also implemented in the rioja package (Juggins 2017).

\section{Radiocarbon dates}

Eleven AMS radiocarbon dates were obtained from the macroscopic plant remains, avoiding any rootlets and other contamination, and one fragment of bone (Table 1). The AMS ${ }^{14} \mathrm{C}$ dates were calibrated using the online calibration program OxCal 4.3 provided by Bronk Ramsey (2009) and the IntCal13 calibration curve (Reimer et al. 2013). Dates are given in calibrated years BC (Table 1). The age-depth model (Fig. 6) was constructed using the algorithm of free shape modelling (Goslar et al. 2009). Additionally, one radiocarbon age was determined for the burnt animal bones. From the previous excavations, carried out in 2003, one more radiocarbon determination of burnt bone from a mammal was available (Bobrowski and Sobkowiak-Tabaka 2016).

\section{Results}

\section{Lithology data and chronology of the core}

The maximum depth of biogenic sediments at the studied site was about $550 \mathrm{~cm}$ (Fig. 2a). Gyttja was found only in 14 profiles and its maximum thickness was about $250 \mathrm{~cm}$ (Fig. 2b). Peat, very often highly decomposed, with silty and sandy components occurred in all profiles. There are a lot of thin layers of fine sand and sometimes a so-called peat matrix - this evidence shows a very dynamic environment. 


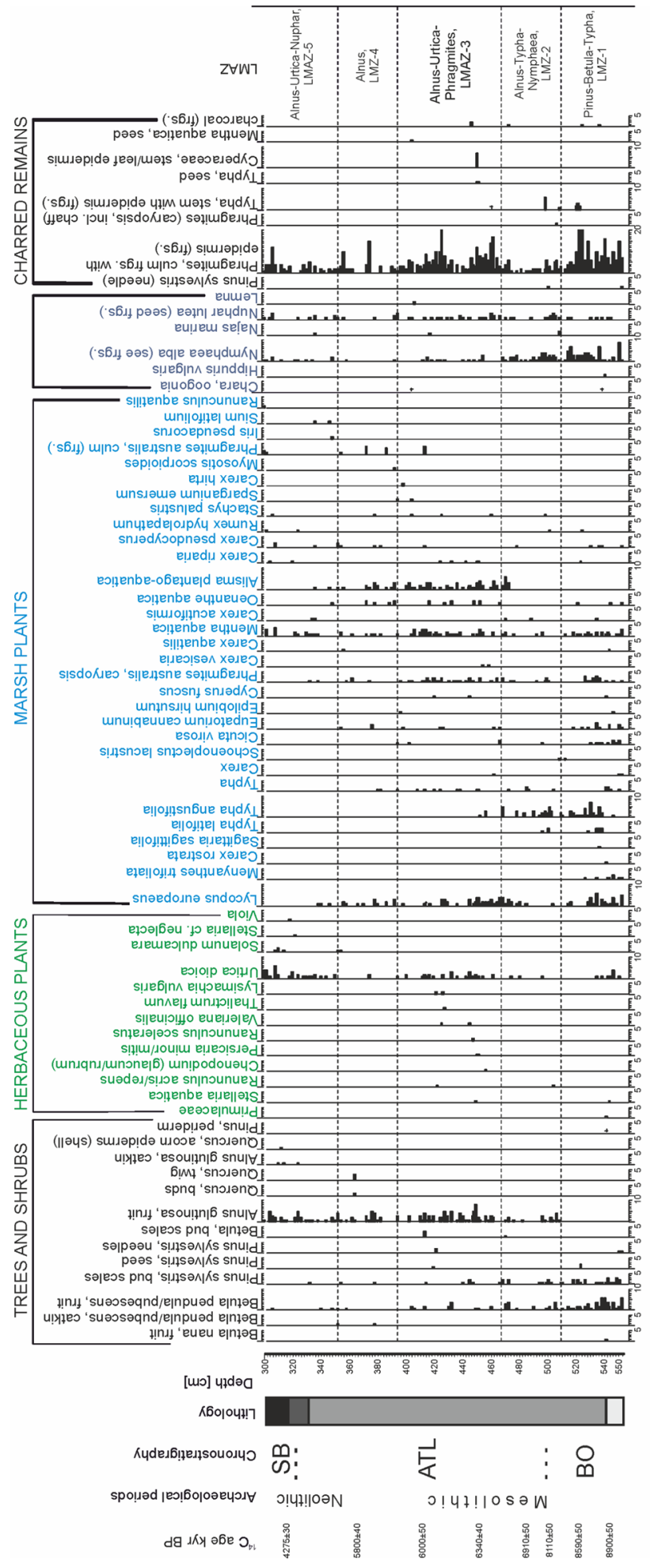

Fig. 5 Macro-remains diagram and chronostratigraphic division of the Kopanica site. LMAZ local macroremains assemblage zones

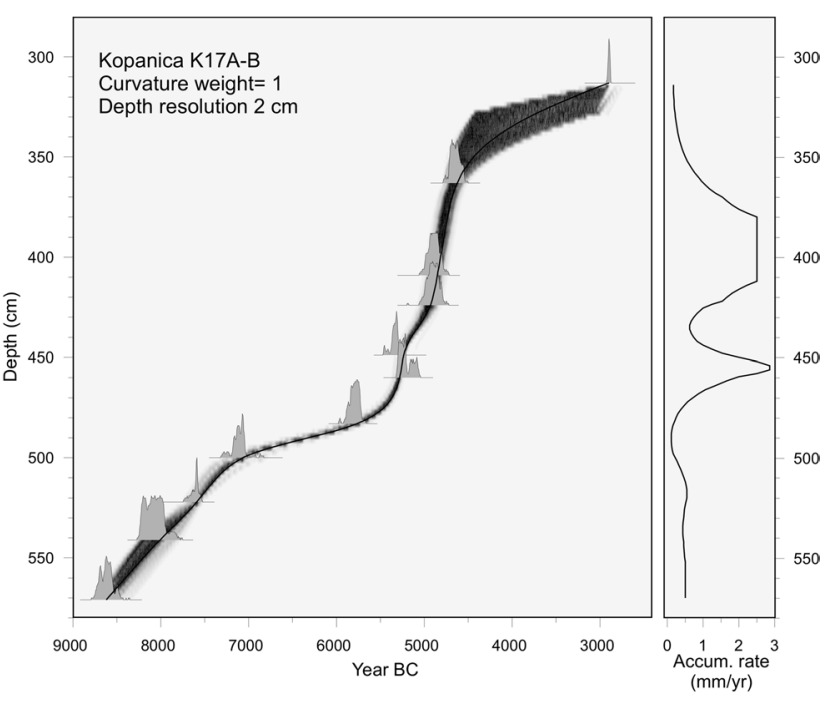

Fig. 6 The age-depth model (radiocarbon dates) and mean sedimentation rate of the Kopanica deposits

The sequence of biogenic deposits sampled for palaeobotanical and geochemical analyses is up to $550 \mathrm{~cm}$ thick and consists of various types of gyttja. The bottommost part $(552-540 \mathrm{~cm})$ was classified as gyttja with sand. The next layer, up to $330 \mathrm{~cm}$, consists of detritus gyttja. In the upper part, coarse gyttja with a high proportion of sand was found. This was overlaid by a layer of coarse detritus gyttja at $316 \mathrm{~cm}$. The presence of plants such as Nuphar and Nymphaea, as well as planktonic Cladocera, reveal aquatic conditions of sediment accumulation.

The results of fieldwork and the presented sedimentary succession suggest that there was a very small lake, not long (verified length is about $500 \mathrm{~m}$ ), very narrow (width about $120 \mathrm{~m}$ ), and meandering (Fig. 2), running collaterally with the axis of the Zbąszyń Lakes tunnel valley. The dominance of clastic components in the gyttja and peat sediments suggests a high intensity of denudation processes (i.e., runoffs and deluvial processes in the catchment area of the lake, also due to man-made pathways).

The results of 11 radiocarbon determinations point to dates from the Boreal to the Early Subboreal (Table 1). The model age is not linear, suggesting a variable sedimentation rate along the core (Fig. 6). The mean rate of sedimentation, as determined from radiocarbon dates, is $0.45 \mathrm{~mm} \mathrm{a}^{-1}$. It fluctuates from low values of $0.12 \mathrm{~mm}$ $\mathrm{a}^{-1}$ at the onset of the middle Holocene to high values of 
$2.9 \mathrm{~mm} \mathrm{a}^{-1}$ during the second part of the middle Holocene (Fig. 6). The pollen diagram does not indicate any hiatuses in the onset of the middle Holocene. Although a hiatus cannot be excluded, it is not probable as the drilling core was selected in the middle of the palaeolake and accumulation of gyttja took place deep in the water at that time. Such a low accumulation rate must have been caused by equable and poor living conditions in the lake.

\section{Pollen analysis}

Two-hundred and nine taxa were identified during the pollen analysis. On the pollen diagram they are divided into six groups: trees and shrubs, herbs, ecologically undefined, ruderals and disturbed habitats, cultivated, and NPPs (Fig. 4). The last group includes algae, fungal remains and charred particles. The content of the terrestrial pollen was the base for CONISS analysis, which allowed for statistical division of the diagram for pollen assemblage zones (LPAZ). Six LPAZ's were distinguished (Fig. 4):

LPAZ I (depth 552-514 cm), early Holocene (Boreal)

The high percentages of Pinus reveals that this tree was the major constituent of the regional vegetation. Corylus was the main admixture and the first thermophilous species expanding after the climate warming in the beginning of the Holocene. This is in agreement with the general pattern of migration of such species in Europe after the last glaciation (Huntley and Birks 1983; Ralska-Jasiewiczowa et al. 2004). Growth of Corylus is limited by both summer and winter temperature (Zagwijn 1994), so its presence reveals real amelioration of climatic conditions. Sambucus nigra, Viburnum opulus and Cornus mas also appeared in the understorey. The Ulmus tree limit line was indicated by low values of elm-less than 1\% (Huntley and Birks 1983). In the younger part of this LPAZ, Pinus slowly decreased and Ulmus and Quercus took over some stands with a significant presence of Corylus. The low content of Betula and Juniperus pollen grains evidences the more closed landscape and poor conditions for these light-demanding taxa. Improvement of the climatic conditions is confirmed by the presence of pollen grains of Ilex aquifolium, which is an oceanic species and sensitive to winter frost (Zagwijn 1994). It is limited to the areas of $-0.5^{\circ} \mathrm{C}$ in the coldest month (Iversen 1944). Salix species created the riparian plant communities together with ferns, Equisetum, Cyperaceae and sedges.

LPAZ II (depth 514-474 cm), early/middle Holocene (end of Boreal and the early Atlantic)

Pinus decreased and was less significant; however, it probably developed mixed forest communities with migrating Quercus and Corylus in the understorey. At the beginning of the Atlantic, following the earliest deciduous trees Ulmus and Quercus, two mesophilous species spread: Tilia and Fraxinus. They were not significant elements of the vegetation and poor soils could be the reason. Pollen grains of both Viscum and Hedera were identified indicating improvement of climatic conditions, with hot summers and mild winters (Iversen 1944). Viscum can tolerate cold winters, $-8{ }^{\circ} \mathrm{C}$ in January, however it needs a warm summer with a mean of $16^{\circ} \mathrm{C}$ in July to flower. Hedera, as an oceanic species, tolerates mild summers with mean of $12-13{ }^{\circ} \mathrm{C}$ in July, but needs mild winters with no lower January mean than $-2{ }^{\circ} \mathrm{C}$ (Iversen 1944; Zagwijn 1994). Both species produce low amounts of pollen, so it is assumed that each pollen record indicates their presence in the area. The regional landscape consisted of a mosaic of deciduous forest with Quercus, Ulmus and Tilia, and Pinus woodland, which, on better soils, was also accompanied by Quercus. There was some pollen representative of open plant habitats, such as Rumex acetosella-type, Plantago lanceolata, Spergulariatype and Plantago maior.

The Boreal Period is the main time for Alnus spreading in Poland (Szczepanek et al. 2004). Such a significant increase of Alnus was found in the area of the Kopanica site. The culmination values exceeding $14 \%$ of the calculation sum indicate that alder was a constituent species in local riparian plant communities. It was accompanied by herbs of wet habitats and telmatophytes such as Solanum dulcamara, Phragmites, Cyperaceae, Typha, Lythrum and Menyanthes trifoliata (Fig. 4).

LPAZ III (depth 474-398 cm), middle Holocene (middle Atlantic)

During the climatic optimum, mixed deciduous forest still existed. Quercus and, to a lesser degree, Ulmus were the most important elements of these plant communities. Tilia and Fraxinus were insignificant or even absent in the area of the research. Tilia pollen grains are poorly dispersed because of the morphology of its pollen grains and entomophily of the tree (Środoń 1991; Kupryjanowicz et al. 2004) and are mostly underrepresented in pollen diagrams. Therefore the extremely low content of Tilia pollen in this phase proves its scarce presence in the region. Isopollen maps suggest an average content of 2-3\% of Tilia for western Poland during the Atlantic, but local environmental conditions must not have favoured this species, which avoids wet, low-lying areas. Similarly, Fraxinus, represented in western Poland at the level of 2\% (Tobolski and Nalepka 2004), in the Kopanica site only exceeds $1 \%$ in spite of favourable wet habitats. Viscum and Hedera are still present, indicating mild winters and hot summers. However, due to their insect pollination, are only represented by single pollen grains (Granoszewski et al. 2004a, b). Ilex aquifolium confirms the mild oceanic climatic conditions. Since ca 5200 BC the proportion of Ulmus increased a little and ca $5000 \mathrm{BC}$ a higher proportion of Quercus is noted. There are few spores of Pteridium aquilinum, and pollen of Rumex, Plantago lanceolata, P. maior and P. media. A. Linum pollen grain was found at the depth 
of $440 \mathrm{~cm}$. It was of the Linum usitatissimum-type, but rather small (42 $\mu \mathrm{m})$ - according to Beug (2004) it comes from $L$. bienne, a wild form and ancestor of cultivated flax (Zohary and Hopf 1988). A few spores of Glomus and Diporotheca and a lot of charred particles were present at that depth. Local habitats were still occupied by riparian plant communities with Alnus as a main constituent.

LPAZ IV (depth 398-358 cm), middle Holocene (late Atlantic)

This period was characterized by the stabilization of forest communities. Quercus and Corylus avellana dominated on elevated, drier areas. Ulmus and Fraxinus formed carrtype communities on slopes. The understorey was represented by Corylus, Prunus, Ribes and Cornus. In wet areas, nearest to the lake, alderwoods occurred. Some taxa like Hedera helix, Humulus, Urtica, Pteridium aquilinum and Calluna vulgaris suggest an existence of forest gaps in different types of forest. Many taxa coming from open areas are assumed to be of anthropogenic origin. Hypericum, Mercurialis annua-type, Polygonum persicaria and Chenopodiaceae belong to this group. The still high content of charred particles and the scarce presence of Glomus and Diporotheca can also suggest human activity in the neighbouring areas.

LPAZ V (depth 358-320 cm), middle/late Holocene (late Atlantic/early Subboreal)

The stability of forest communities decreased because of the lower proportion of Ulmus. Tilia disappeared almost completely. Proportions of Pinus, Betula and Corylus are unchanged. A single grain of Viscum was found, the youngest one in the diagram, which confirms the final stage of climatic optimum, wetter conditions and the coming of the mild climate of the Subboreal. The local culmination of Alnus suggests the periodical increase of alder woods. The still high content of telmatophytes [Cyperaceae, ferns, Typha latifolia and (probably) T. angustifolia] implies good conditions for the development of wet habitats. The very high content of Urtica (above 5\%) reveals eutrophic nitrogen-rich habitats occurring either in natural carrs and alder woods or in plant communities influenced by humans. Indicators of open places show some gaps in dense woods. A few remains of Diporotheca and a lot of charred particles were found.

LPAZ VI (depth 320-300 cm), late Holocene (Subboreal)

Regional vegetation changed due to the decrease of Pinus and the increase of Quercus and Tilia. Betula declined due to dense forest canopy along with the light-demanding Juniperus and Poaceae. Mixed deciduous forest was more significant than before. The disappearance of Viscum suggests a slow deterioration of (thermic) climatic conditions after the Atlantic optimum of the Holocene. The persistent presence of Hedera helix indicates a mild, oceanic climate. Due to such a change, a clear spread of Alnus was found, probably in alder carr vegetation. In wet habitats, Typha (T. latifolia, Sparganium emersum-type), Cyperaceae (Carex-type,
Cyperaceae) and ferns still occurred. The content of charred particles was much smaller compared to the previous phases.

\section{Plant macroremains}

Five local macrofossil assemblage zones (LMAZs), consisting of local vegetation and occurrences of macroscopic charred plant remains were described (Fig. 5).

LMAZ-1 (depth 552-509 cm), Pinus-Betula-Typha: early through mid-Boreal

What clearly emerges from the macrofossil assemblages is the presence of Pinus sylvestris (Scots pine) remains accompanied by the macrofossils of Betula pendula/pubescens (tree birches), which suggests that both pine and tree birches were locally well represented in the Boreal forest cover.

The macrofossil analysis also revealed the presence of marsh plants in the close vicinity of the sampling site: Typha (bulrush) (both species T. angustifolia and T. latifolia), Phragmites (reed), Eupatorium cannabinum (hempagrimony), Mentha cf. aquatica (water mint), Lycopus europaeus (gipsywort), Epilobium hirsutum (willowherb), Cicuta virosa (water hemlock), Oenanthe aquatica (waterdropwort), Menyanthes trifoliata (bogbean) and various sedges (Carex aquatilis, C. riparia, C. pseudocyperus, $C$. acutiformis and $C$. rostrata). They all would have grown in wet or swampy places along the water margins and in marshes. Some of these species are tall herbaceous plants, and their diversity suggests well-developed marsh vegetation. Plants indicative for open water such as Nymphaea alba (white water-lily), Nuphar lutea (yellow water-lily) and Hippuris vulgaris (mare's-tail) were also found. The water must have also been inhabited by aquatic animals such as fresh-water sponges (Porifera) and moss animals (Bryozoa).

The regular presence of charred Phragmites culm fragments, Phragmites leaf/culm epidermis, and (in a few samples) Typha stem fragments (with epidermal surface) show that the local marsh vegetation was subjected to fires during this phase. There are also finds of macroscopic wood charcoal in a few samples. Even though there is no archaeological evidence for human presence in the area during this time, it is very possible that the area was visited by Early Mesolithic groups and that human activity is most likely responsible for the episodes of recurrent burning of marsh vegetation.

The presence of macrofossils from plants typical of places with high levels of nutrients, such as Urtica dioica (stinging nettle) and Stellaria aquatica (water chickweed), may suggest an increased input of nitrogen in the soil. The input of nutrient, however, may have been either anthropogenic or natural, for example in locations along the bodies of nutrient-rich (eutrophic) waters. 
LMAZ-2 (depth 509-467 cm), Alnus-Typha-Nymphaea: late Boreal-early Atlantic

This zone is characterized by the first appearance of Alnus glutinosa remains in the macrofossil record. There are also scattered but regular finds of Pinus and Betula. The diversity of marsh species and their frequencies in this zone are significantly lower than in the previous zones. Typha and Phragmites seem to be the dominant species in the marsh vegetation along the water margin. Nymphaea alba is well represented throughout the zone and, in some samples, is accompanied by Nuphar lutea. The presence of Najas marina (holly-leaved naiad) in the lowermost sample of this zone, suggests the improvement of climatic conditions, as this thermophilic plant acquired its maximum development during the Atlantic optimum.

Also characteristic for this zone are regular occurrences of charred fragments of Phragmites culms (stems), which in some samples are accompanied by isolated epidermis fragments. In one sample, a charred Phragmites caryopsis (fruit), still partially enclosed in its chaff, was also found. In another two samples, charred fragments of Typha stem or leaf were preserved. The charred assemblage was also characterized by the presence of Pinus needle remains and a single piece of macroscopic charcoal. As in the previous period, the presence of charred plant remains may possibly be explained as human activity in the area (even though there is no archaeological evidence for human presence). It seems that reed, and other marsh plants, would have been selectively and recurrently burnt.

LMAZ-3 (depth 467-394 cm), Alnus-Urtica-Phragmites: mid Atlantic

There are regular finds of Alnus glutinosa, and only scattered finds of Pinus and Betula. This zone is also characterized by the regular occurrence of Urtica dioica. Typha, which was a significant element of local marsh vegetation in the previous zones, now seems to be present to a smaller extent. Phragmites seems to be more important; it would have formed belts/stands of marsh and shore vegetation. Other marsh plants identified in the macrofossil assemblage included Alisma plantago-aquatica (water-plantain), Lycopus europaeus and Mentha aquatica. All occurred regularly through the zone, and were sporadically accompanied by Stachys palustris (marsh woundwort), Eupatorium cannabinum, Sparganium emersum (branched bur-reed) and sedges. The finds of Nuphar lutea are consistently recorded, whereas Nymphaea alba occurs less regularly when compared with previous zones. This feature may indicate a lowering of the water level. The presence of Najas marina may speak in favour of warmer climatic conditions.

The noticeably regular occurrence of Urtica dioica may be associated with soil enrichment, with extra nitrogen as a result of human activity in the area. Human activity may also be responsible for the regular presence of charred vegetative remains of Phragmites (stem fragments, epidermal remains), charred seeds of Typha cf. latifolia and charred seed remains of Mentha aquatica. It is possible that these charred remains are the result of deliberate burning of marsh vegetation, reed beds in particular.

LMAZ-4 (depth 394-352 cm), Alnus: late Atlantic

Macrofossils have low frequencies and sporadic occurrences compared with the previous zones. The diversity of species in this zone is also lower than in the previous zones. There are scattered but regular finds of Alnus and only single records of Betula, Pinus and Quercus, low frequencies of marsh plants (Typha, Phragmites, Alisma plantago-aquatica, Mentha aquatica, Lycopus europaeus), and sporadic finds of water plants (Nymphaea alba and Nuphar lutea).

Charred vegetative remains of Phragmites are recorded only occasionally, which suggests that fire episodes may have been less frequent than in the earlier periods.

LMAZ-5 (depth 352-300 cm), Alnus-Urtica-Nuphar: late Atlantic-early Subboreal

Also in this zone, the regular occurrences of Alnus glutinosa remains in the macrofossil record suggest well established stands of this tree on damp soils. Its preferred habitat is alder carr and/or riparian forest. Solanum dulcamara (bittersweet) would have also grown among the alder carr vegetation. Urtica dioica would have been well represented in the local vegetation. Typha is no longer present in the macrofossil record. There are scattered finds of a few other marsh plants including Phragmites, Rumex hydrolapathum, Stachys palustris, Mentha aquatica, Lycopus europaeus and a few sedges. Water plants occur more regularly compared with the previous zone, yet are represented only by two species: Nuphar lutea, dominant in the records, and Nymphaea $a l b a$, which occurs only sporadically.

The macroscopic finds of charred vegetative tissue (mainly stem fragments of Phragmites, also stem/leaf epidermis) show a regular presence through the entire zone.

\section{Diatom analysis}

One-hundred and nine diatom species were recorded (Fig. 7). The diatom flora in the analysed section of the core was sparse and poorly preserved. Some parts of the core were completely devoid of diatom valves (i.e., $572-374 \mathrm{~cm}$ ). Five local diatom assemblage zones (LDAZ) were distinguished based on statistical division.

LDAZ 1 (depth 374-370 cm) consisted of diatom flora assemblages that reflected a relatively high water level. Planktonic species (60-69\%) dominated with the addition of species classified as periphyton (23-25\%). Dominant among planktonic forms were Aulacoseira ambigua, Ellerbeckia arenaria and Cyclotella radiosa, C. choctawhatcheana. Among the periphytonic the most 


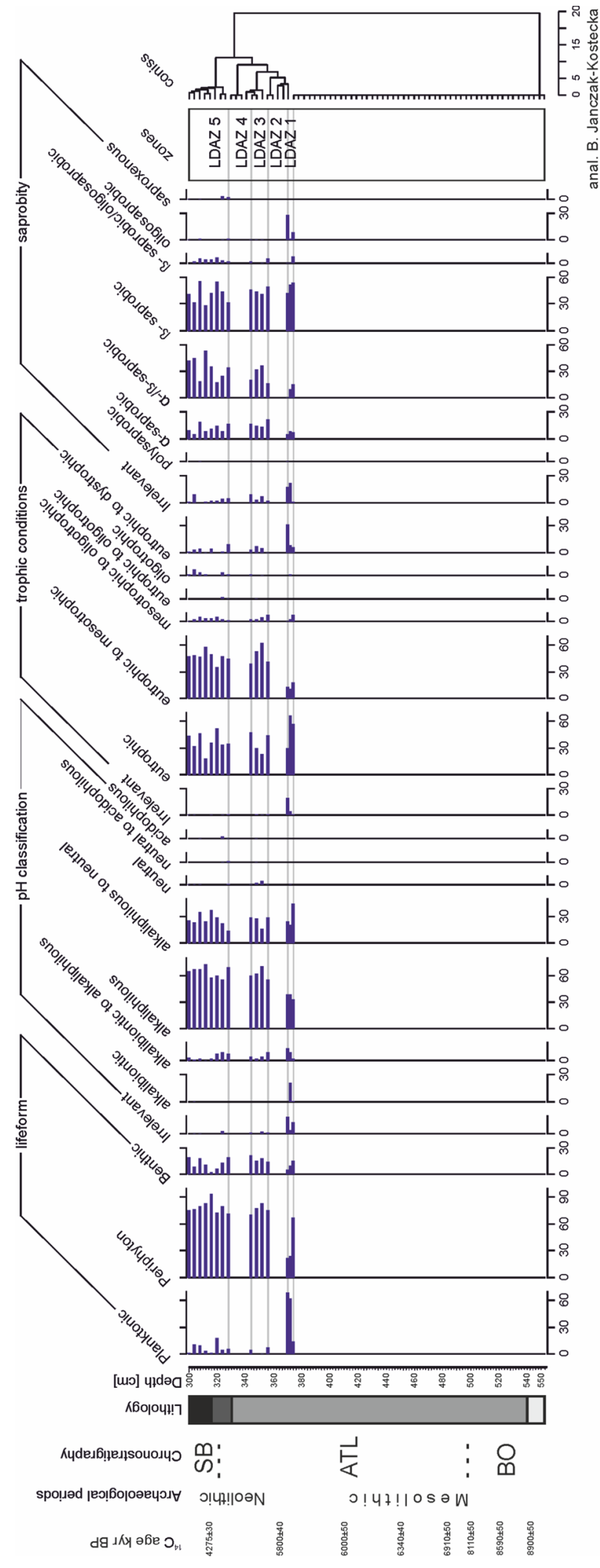

Fig. 7 Diatoms diagram and chronostratigraphic division of the Kopanica site. $L D A Z$ local diatom assemblage zones numerous were Staurosirella martyi, Staurosirella pinnata, Pseudostaurosira brevistriata, Amphora ovalis, A. pediculus and Epithemia adnata. The diatom composition indicated alkaline and alkaline to neutral waters, eutrophic with a moderate quantity of nutrients and with a moderate to heightened content of electrolyte, $\beta$-mesosaprobic as moderately contaminated. Diatom assemblages are typical for eutrophical water ponds and lowland lakes.

LDAZ 2 (depth $370-356 \mathrm{~cm}$ ) consisted of damaged diatom valves with a few fragments that preclude identification.

LDAZ 3 (depth $336-344 \mathrm{~cm}$ ) is characterized by the domination of periphytonic species: Ulnaria ulna, Pseudostaurosira brevistriata, Staurosirella pinnata, Cocconeis placentula and $C$. lineata. The trophic tolerance is wide. The occurrence of $\beta$-mesosaprobic taxa indicates a moderately contaminated environment.

The depth of 344-328 cm was identified as zone LDAZ 4 ; it was devoid of diatom valves.

The uppermost zone, LDAZ 5 (328-300 cm), consisted of diatom assemblages dominated by periphyton taxa: Ulnaria ulna, Fragilaria brevistriata, Cocconeis placentula and $C$. lineata. These are diatoms typical for eutrophic to mesotrophic, alcalic waters with $\beta$-mesosaprobic, indicating moderately contaminated waters.

\section{Cladocera analysis}

The studied sediments contained 26 Cladocera species, belonging to four families: Bosminidae, Daphnidae, Chydoridae and Sididae. The cladoceran assemblages were mainly characterized by the dominance of the Chydoridae family, which is typically associated with benthic habitats. The planktonic taxa occurred in small proportions and reached only $0-12 \%$ in the assemblage. The frequency of Cladocera ranged from 200 to 6,320 individuals per $\mathrm{cm}^{3}$. No cladoceran remains occurred at $318 \mathrm{~cm}$ and $326 \mathrm{~cm}$. Based on the composition and abundances of species, seven local cladoceran assemblage zones (LCAZ) have been distinguished (Fig. 8).

LCAZ I (depth 552-512 cm): the frequency and diversity of cladoceran fauna was relatively low (not exceeding 13 taxa and 1,720 specimens). Macrophyte/sediment-associated taxa, such as Chydorus sphaericus, Alona rectangula and Alona affinis dominated; however, macrophyte-associated Acroperus harpae and Alonella nana were quite abundant. Pelagic forms (Bosmina (Eubosmina) coregoni and Bosmina longirostris) and other taxa occurred sporadically, not exceeding $10 \%$ of the total amount of Cladocera.

LCAZ II (depth 512-480 cm): an increase in frequency and diversity of cladoceran fauna (exceeds 19 taxa and 6,380 specimens). Similarly to the previous zone, Ch. sphaericus, A. rectangula, Ac. harpae and A. affinis still dominated. 


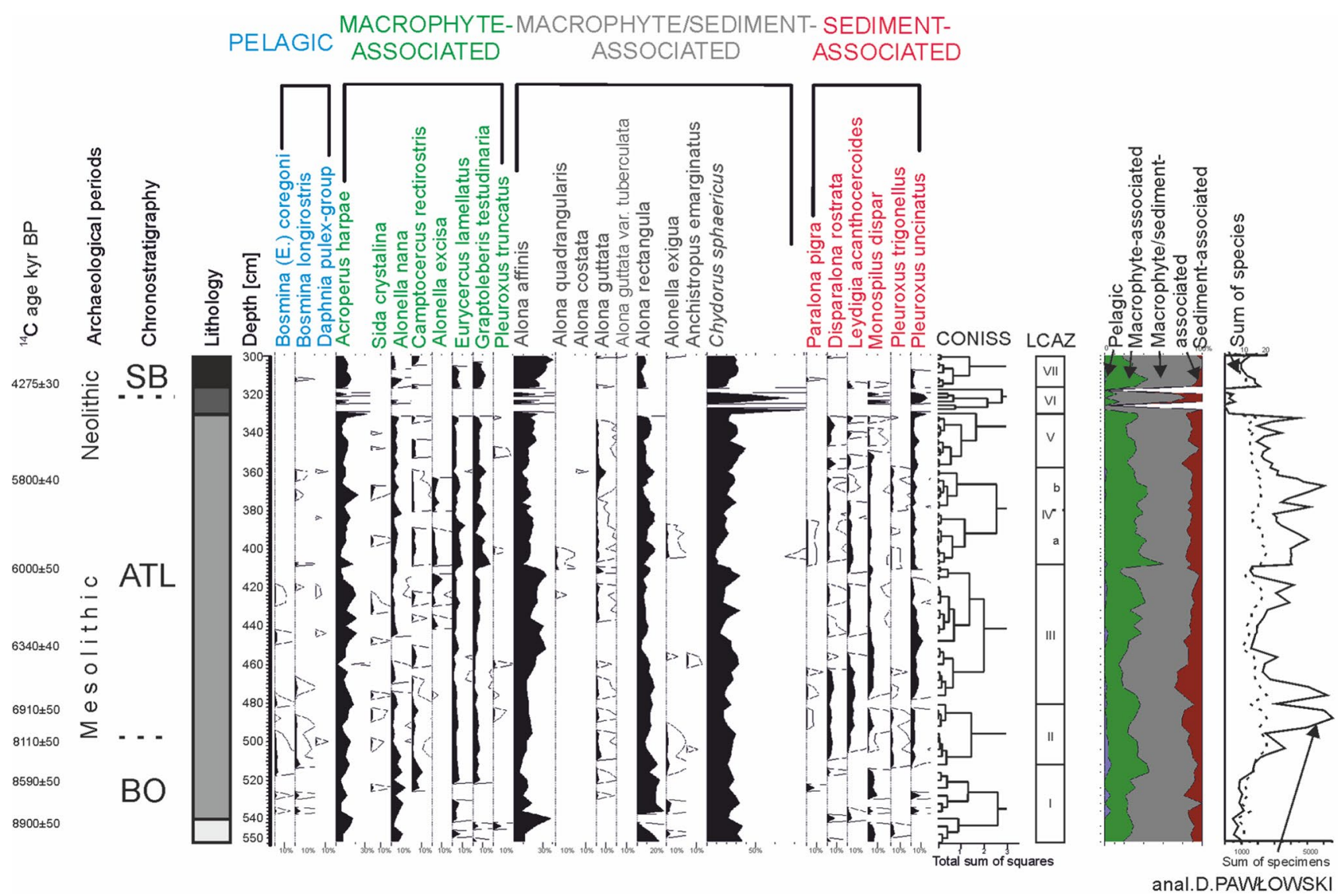

Fig. 8 Cladocera percentage diagram, total sum of species and specimens and chronostratigraphic division of the Kopanica site. $L C A Z$ local cladocera assemblage zones

However, the sediment-associated taxa such as Disparalona rostrata, Leydigia acanthocercoides, Monospilus dispar, Pleuroxus uncinatus and P. trigonellus were becoming more and more numerous. The almost constant occurrence of pelagic taxa (B. longirostris, B. (E.) coregoni and D. pulexgroup) did not exceed $10 \%$ of the total Cladocera amount.

LCAZ III (depth 480-408 cm): a decrease in frequency and diversity of the Cladocera (from 6,180 to 1,560 specimens, and from 19 to 9 taxa). Fossils of Ch. sphaericus, A. affinis and Ac. harpae dominated. The sediment-associated taxa exceeded $30 \%$ of the total Cladocera amount. At the end of this section, the macrophyte-associated taxa became more numerous. Pelagic taxa occurred sporadically.

LCAZ IV (depth 408-358 cm): Cladocera numbers and species fluctuated (from 2,760 to 6,000 specimens, and from 12 to 19 taxa) and therefore two subzones were distinguished. The pelagic forms still appeared occasionally.

LCAZ IVa (depth $408-380 \mathrm{~cm}$ ): fossils of A. affinis dominated. However, macrophyte/sediment-associated taxa such as $C h$. sphaericus, $A$. rectangula were becoming more numerous. The macrophyte-associated taxa such as G. testudinaria and E. lamellatus were quite abundant. At the same time there was an increase in the frequency of sediment-associated taxa such as $P l$. uncinatus, L. acanthocercoides, M. dispar, Paralona pigra and $D$. rostrata, which exceeded $20 \%$ of the total number of caldocerans.

LCAZ IVb (depth 380-358 cm): fossils of Ch. sphaericus dominated. A slight decrease of $A$. rectangula was observed. The frequency of macrophyte-associated taxa such as Ac. harpae was still relatively high. The sedimentassociated taxa were slightly less abundant. Pelagic taxa (B. longirostris and D. pulex-group) occurred sporadically.

LCAZ V (depth 358-330 cm): systematic reduction of Cladocera numbers and species (from 4,460 to 240 specimens and from 14 to 4 taxa) was observed. Pelagic taxa did not occur. Fossils of A. affinis $C h$. sphaericus and $A$. rectangula still dominated. The abundance of sedimentand macrophyte-associated taxa decreased slightly.

LCAZ VI (depth 330-316 cm): the frequency and diversity of cladoceran fauna was very low (not exceeding 6 taxa and 300 specimens) and included only fossils such as Ch. sphaericus, A. affinis, Ac. harpae, Al. nana, M. dispar and $P l$. uncinatus which occurred sporadically. 
LCAZ VII (depth 316-300 cm): an increase in the frequency and diversity of cladoceran fauna (exceeds 2,140 specimens and 12 species). The littoral, macrophyte/sediment-associated taxa still dominated, with Ch. sphaericus and $A$. affinis. The macrophyte/sediment-associated taxa such as Ac. harpae and G. testudinaria were quite abundant. Both sediment-associated and pelagic taxa did not exceed $10 \%$ of the total amount of Cladocera.

\section{Geochemical data}

The analysed sections of cores K17A and K17B were subdivided into six local geochemical units (LGU1-LGU6) (Fig. 9). The content of terrigenous silica reflected variations in mineral material input from the catchment area; biogenic silica and organic matter are interpreted as being the result of variations in biogenic production in the water reservoir while changes in the contents of $\mathrm{Na}$, $\mathrm{K}, \mathrm{Mg}$ and $\mathrm{Fe}$ are seen as a reflection of changes in the erosion of the catchment area. Calcium carbonates and $\mathrm{Ca}$ contents in the lacustrine sediment are the result of accumulation from fauna shells or input from the lake drainage area. The iron to manganese $(\mathrm{Fe} / \mathrm{Mn})$ ratio and Mn content are often used to reconstruct oxidation and reduction conditions.

LGU1 (depth 552-512 cm) revealed a high content of terrigenous silica (74-92\%), slight fluctuations of Na content
$(0.02-0.1 \%)$ and low values of the rest of the analysed geochemical parameters.

LGU2 (depth 512-480 cm) is conspicuous with upwardly increasing contents of organic matter (from 19 to 43\%), calcium carbonates, $\mathrm{Na}, \mathrm{K}, \mathrm{Ca}, \mathrm{Mg}$, $\mathrm{Fe}$ and with a low content of terrigenous silica $(12-40 \%)$.

LGU3 (depth 480-444 cm), is characterised by an upwardly increasing content of terrigenous silica and by a decrease of the rest of the analysed parameters.

LGU4 (depth 444-400 cm) and LGU5 (depth $400-326 \mathrm{~cm})$ are similar and reflected distinct fluctuations of the contents of organic matter (6-35\%), calcium carbonates $(0.3-3.7 \%)$, biogenic silica (1-44\%), $\mathrm{Na}(0.02-0.1 \%)$, $\mathrm{K}(0.006-0.03 \%), \mathrm{Ca}(0.6-4 \%), \mathrm{Mg}(0.01-0.16 \%), \mathrm{Mn}$ $(0.005-0.2 \%), \mathrm{Fe}(0.1-4.3 \%)$, and the $\mathrm{Fe} / \mathrm{Mn}$ ratio, with distinct peaks at depths of 400,384 and $344 \mathrm{~cm}$.

LGU6 (depth 326-300 $\mathrm{cm}$ ) revealed a distinct upward increase of organic matter (from 3 to $20 \%$ ) and $\mathrm{Fe} / \mathrm{Mn}$ ratio (from 24 to 150) with slight fluctuations of the rest of the analysed parameters.

\section{Discussion}

Although fire in the middle Holocene has often been associated with climatic factors and the composition of natural vegetation, we suggest, as have others (Dietze et al. 2018),

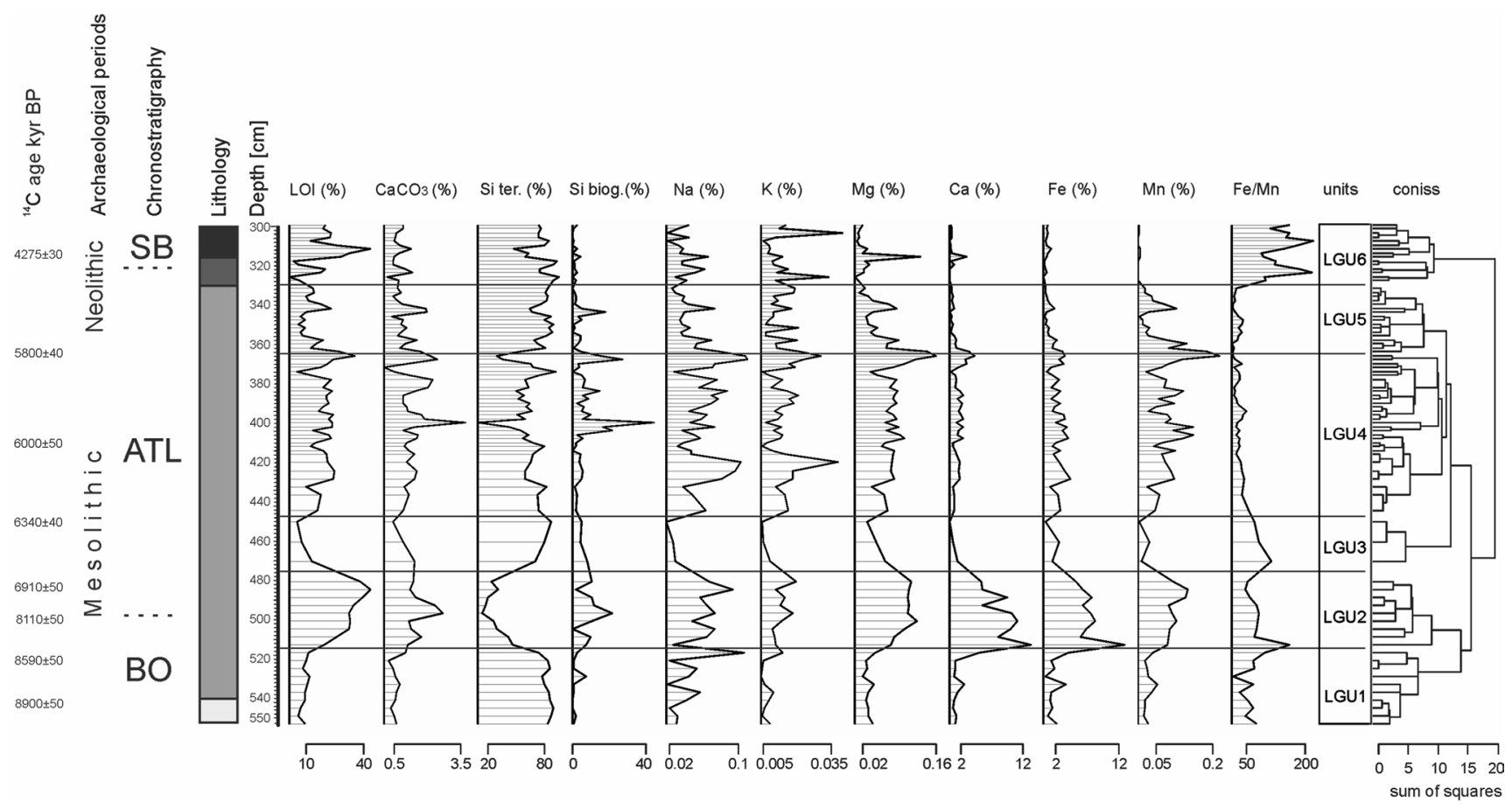

Fig. 9 Geochemical data from Kopanica. $L G U$ local geochemical units 
that charred plant remains that are preserved in macroscopic and microscopic records allow detection of Mesolithic activities despite low population densities. Latałowa (1992) concludes that regular fires on sandy soils favour the development of a rich herbal layer with Pteridium aquilinum as a dominant species because of its preference for ash content in the soil. In the pollen diagram from Kopanica, P. aquilinum developed constantly since 7500 BC together with the increase of Calluna vulgaris and Vaccinium pollen types as indicators of a loose forest canopy (Fig. 10).

Some disturbance of the forest and evidence for open areas in the forest may be indicated by the presence of understorey taxa or herbs in the pollen record. Artemisia, Calluna vulgaris, Pteridium aquilinum and Juniperus occurred in patches of pine-forest. Frangula, Viburnum opulus and Sambucus nigra-type appeared in deciduous woodlands of different types. Melampyrum was observed as being more frequent when indicators of human activity increased (Behre 1986). There were also many species coming from open plant communities typical today for wet or fresh meadows (Rumex acetosa, Valeriana officinalis, Fallopia convolvulus) or dry, sandy habitats (Centaurea scabiosa, Mercurialis annua, Jasione, Rumex acetosella-type, Artemisia). Open areas in the forest were indicated by many species from an "ecologically undefined" group: Aster-type, Anthemis-type, Cichorioideae, Hypericum, Lotus-type (Latałowa 1992; Ralska-Jasiewiczowa and van Geel 1998).

The changes related to the presence of Mesolithic groups in the Kopanica area have also been detected by other analyses. Pediastrum boryanum is a species of green algae indicative for high-trophy conditions (Komárek and Jankovská 2001). It culminates at ca 6800, 5400, 5300 and 4900 BC, suggesting meso- or eutrophic conditions in the lake (Fig. 10). Since ca 5300 вс Glomus and since ca 5200 вс Diphorotheca remains occasionally appeared. They are indicative for erosional processes (van Geel and Aptroot 2006), which could be related to human presence in the lake catchment. It is also highly probable that the presence of Urtica dioica between ca 5300 and 4800 BC may indicate human activity in the area (Fig. 10).

This species usually grows on humid and nitrogen-enriched soils of alder carrs. It is indicative for episodic openings in dense woods and/or human-induced increase of trophy.

The presence of charred plant remains in both macroscopic and microscopic records from Kopanica is of particular interest to us because it suggests that local fires would have burned at or near the site. The question is whether these fires were natural or anthropogenic, induced by Mesolithic groups who visited the area during the Boreal and particularly during the Atlantic. A comparison of both macroscopic and microscopic records reveals that the charred particles derived mainly from herbaceous plants (see Fig. 10). The macroscopic record shows that they were mainly charred

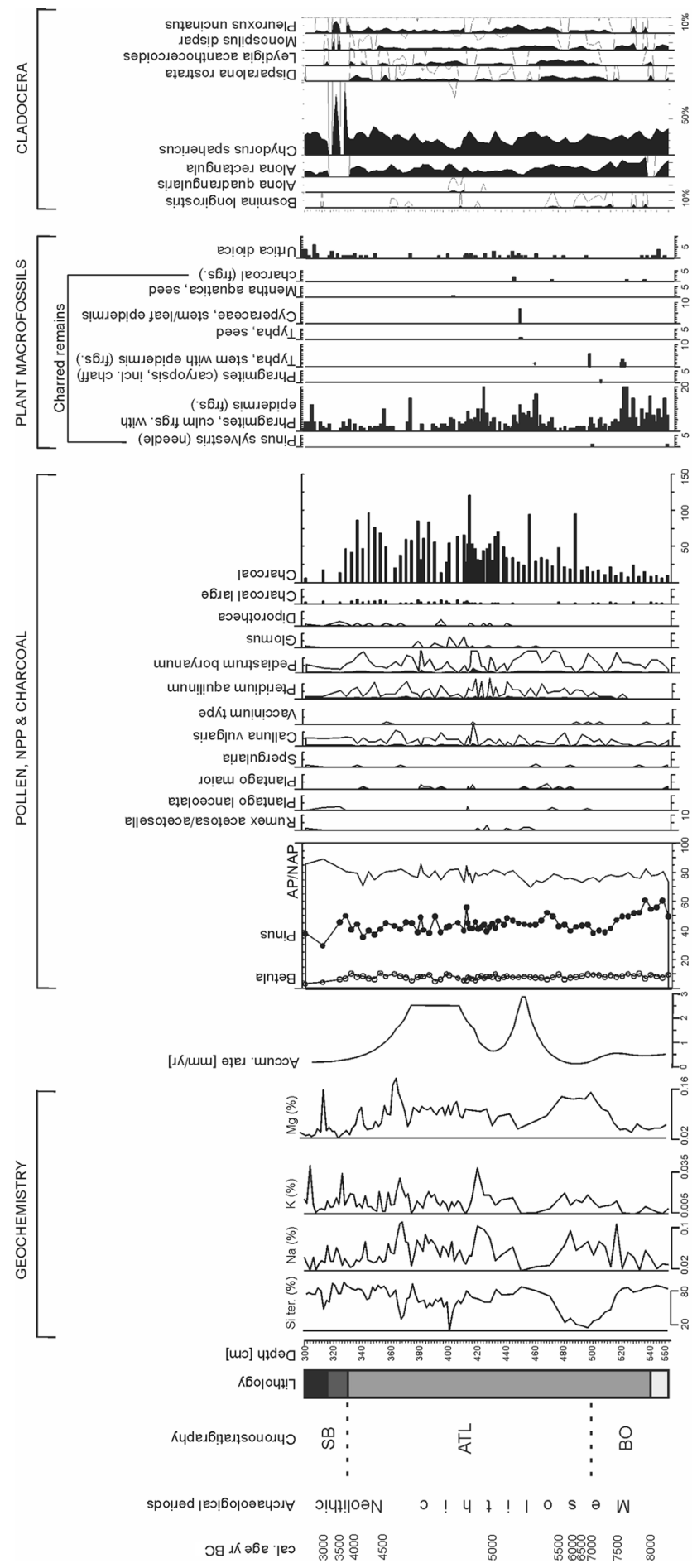

Fig. 10 Summary diagram of lithology, chronology, selected indicators of pollen, macro-remains, Cladocera, and geochemical data

culm fragments of Phragmites (see Fig. 11a) and occasionally stem/leaf fragments of Typha that were deposited in gyttja sediments. In addition to charred vegetative parts, charred seed remains of Phragmites, Typha (see Fig. 11b) and Mentha were also recorded. Only occasionally were 

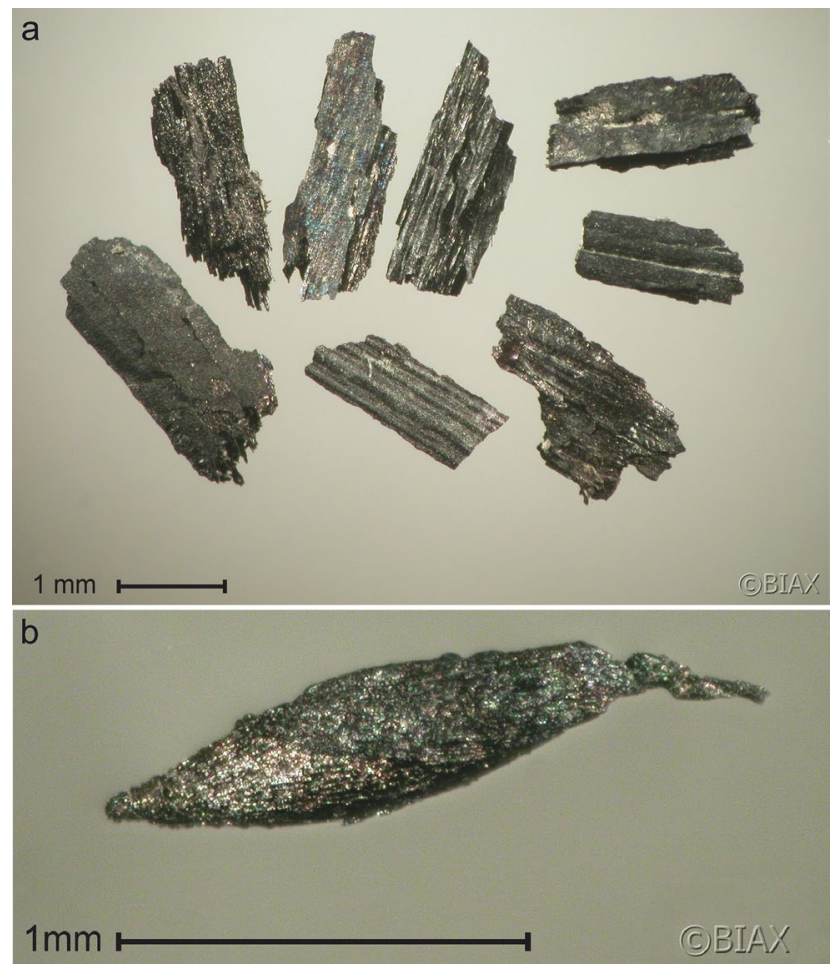

Fig. 11 Kopanica K17A-17B, a charred stem fragments of reed (Phragmites), recovered from sample 460, b charred seed of bulrush (Typha cf. latifolia), recovered from sample 450, both samples are dated to early Atlantic and are associated with the Late Mesolithic use of the site

Pinus needle fragments and Pinus wood charcoal present in the macrofossil record. Microscopic particles found in the pollen samples derived mainly from charred leaf/stem epidermis of grasses (including Phragmites), which is suggested by a characteristic deep-wavy appearance of charred epidermal cell walls (ESM). Microscopic charcoal particles were noticed occasionally. What is truly interesting about the charred macroscopic and microscopic assemblages is the fact that a significant majority of the charred remains derived from marsh vegetation (Phragmites in particular). It is rather unlikely that natural fires would start in this vegetation zone. Instead, the deliberate burning of marsh vegetation by the Mesolithic groups who frequented the area is a most plausible scenario. This, however, does not exclude the occurrences of fire in a forest, on dry ground. These fire episodes may have been responsible for the presence of charcoal particles in the Kopanica macroscopic and microscopic assemblages, and for disturbances and openings in the forest, which are indicated by the pollen spectra. The cause of fire may have been natural-or induced deliberately by people, to create a living area, for example. Some of the charcoal particles may have simply derived from hearths and/or cooking fires.

The evidence for the burning of local marsh vegetation at other hunter-gatherer sites in temperate Europe has been presented earlier. One of the best documented examples of intentional and recurrent burning of reed beds comes from the Early Mesolithic site at Star Carr in England (Hather 1998; Law 1998). The burning of marsh vegetation was also suggested for the Early and Middle Mesolithic river dune site at Rotterdam-Yangtzehaven in the Netherlands (KubiakMartens et al. 2015).

The burning of local marsh vegetation may, however, be older than the Mesolithic tradition. For example, in Całowanie (in central Poland), charred remains of marsh plants were found in the Early Mesolithic but also in the Late Palaeolithic macrofossil assemblages (Kubiak-Martens and Tobolski 2014). Human-induced fires are clearly indicated in charred microscopic and macroscopic assemblages from other sites in the Wojnowo Region (dated to the Late Palaeolithic and Early Mesolithic), including those from earlier studies of the Kopanica site (Kubiak-Martens 2016; Okuniewska-Nowaczyk 2016). Also, charred macroscopic and microscopic remains of marsh plants from Lubrza (in western Poland) indicate that various activities associated with the presence of the Late Palaeolithic Federmesser and, later, the Swiderian groups in the area, such as setting up camp fires and also the burning of marsh vegetation, are likely to be responsible for the occurrence of charred remains (Sobkowiak-Tabaka et al. 2018).

Therefore, we suggest that the occurrences of charred remains in the Kopanica sequence dated between ca 8200 and 7500/6000 $\mathrm{BC}$ (and probably earlier), followed by an increase of these remains between ca $5500-4600 \mathrm{BC}$, is associated with use of fire by Mesolithic hunter-gatherers. This period also coincides with a cycle of human fire usage in land management, especially in northern and eastern Germany, and northeastern Poland, between ca 6500 and 4000 BC $(8,500-6,000$ cal вP; Dietze et al. 2018). Although in this period the general fire trend is decreasing, we can observe some periods of fire trends which increase in the Late Mesolithic and which could coincide with our results. The maxima in charred remains at the Kopanica site peaked at ca 5300, 4900, and 4700 вс (Fig. 9). The Mesolithic groups who made recurrent visits to the Kopanica area during the middle Holocene would have deliberately set fire to the local marshes. This was, perhaps, to improve hunting strategy (Mellars 1976) or to increase the yield of plant foods (e.g., Innes and Blackford 2003) or just to improve (and maintain) access to open water.

Large amounts of burnt flint and bone artefacts may be a result of using fireplaces at the camp. However, due to dry, acidic sandy soils, which offer poor preservation conditions (Sergant et al. 2006), neither hearths, ashes nor burnt ground were registered during excavations. Two more explanations are worth taking into consideration. The first one refers to the aforementioned (natural) fires, producing temperatures high enough to damage archaeological remains 
(Stahlschmidt et al. 2015). The second one is the burning of vegetation by Mesolithic groups who repeatedly frequented this area.

Preliminary results of use-wear analysis, conducted by Bernadeta Kufel-Diakowska, showed the use of artefacts as projectiles, and the processing of game, hide and also herbaceous plants with high silica content. Both pollen and macro-remains of such plants, i.e., Phragmites, Carex sp., Typha sp., Equisetum sp. and Artemisia, were recorded in biogenic sediments from the studied core (Figs. 4, 5). Plant fibres and twigs played an important role in manufacturing various types of containers, ropes, mats, bags etc. (i.e., Osipowicz 2019; Sobkowiak-Tabaka and Kufel-Diakowska 2019).

The aquatic invertebrates at the Kopanica site occurred in considerable numbers throughout the investigated sediment core (Figs. 8, 10). Some of the cladoceran taxa can be considered significant indicators for the increase of laketrophy: Bosmina longirostris, Alona rectangula, Chydorus sphaericus, Leydigia acanthocercoides, Pleuroxus unicnatus, Disparalona rostrata and Alona quadrangularis (Whiteside 1970; Szeroczyńska 2002; Pawłowski 2011). Therefore, based on changes in the Cladocera assemblages, we can distinguish several phases of trophy increase at Kopanica between ca 7200 and 4600 BC. Although the increased trophic status of the lake at Kopanica during the middle Holocene was probably related to natural processes associated with favourable climate conditions rather than to the Late Mesolithic settlement, we can consider such situations. Generally, lake sediment columns located at the frequently populated areas of human occupation record the strongest aquatic assemblage responses in the cultural layers, since these areas would receive the highest amount of organic material causing increased nutrient concentration and biological productivity (Tóth et al. 2019). It would be logical to assume that the economic activity of Mesolithic groups of hunter-gatherers mainly focused on forested areas and lakeshores where they cleared the undergrowth with fire. Such activity does not indicate a massive organic material load into the lake water, as was the case in later cultural periods (Szeroczyńska 2002; Kittel et al. 2014). However, it is possible that aquatic invertebrate assemblages in the water at Kopanica from the Mesolithic layers exhibited weaker but also consistent biological responses. During periods of increased lake-trophy in ca 7200-5300 BC and 5100-4600 BC (Fig. 9), a clear decrease in water quality during the deposition of the cultural layers is supported by the appearance of cladocerans (Chydorus sphaericus, Alona rectangula, Pleuroxus uncinatus, Leydigia acanthocercoides, and Disparalona rostrata) which are tolerant of fertile/turbulent water (Kittel et al. 2014; Pawłowski et al. 2016a). On the other hand, between these periods, the temporary increase of the Monospilus dispar taxon (a sediment-dwelling species, preferring higher water transparency and mesotrophic conditions) in the lake has been observed (Frey 1986; Pawłowski et al. 2013). Therefore, we have also assumed that the presence of aquatic invertebrates in the lake at Kopanica indicated that human impact likely resulted in mineral material loading and, to a lesser degree, nutrient input into the water during the cultural period. This thesis confirms the results of geochemical analysis and the higher sedimentation rate (ca $2.5 \mathrm{~mm} /$ year during ca 5100-4600 BC). During ca 5100-4600 BC (Fig. 10) particularly distinct fluctuations of the contents of soluble metals $(\mathrm{Na}, \mathrm{K}$ and $\mathrm{Mg}$ ) and the concentration of $\mathrm{Si}_{\text {ter }}$ reflected input of these elements from the catchment area as the result of intensive erosion of mineral soil and a low level of leaching. Jones and Keen (1993) reported examples of a greater influx of $\mathrm{Na}, \mathrm{K}, \mathrm{Mg}$ and $\mathrm{Fe}$ to the sediments of the lakes that were the result of heightened mineral soil erosion after forest destruction within the catchment area. Similarly, an increased concentration of $\mathrm{Si}_{\text {ter }}$ and increasing values of $\mathrm{Na}$ and $\mathrm{K}$ may indicate drastically enhanced mechanical denudation in the immediate vicinity of the study site (Pawłowski et al. 2016b), or shows the coincidence of human activity and the physical erosion of the catchment (Pawłowski et al. 2015). However, some periods of enhanced erosion and changes in trophic status of the lake are partly shifted in time in contrast with periods of particularly distinct concentrations of charred microscopic and macroscopic remains, especially between ca 5300 and 5100 BC (Fig. 10); this phenomenon may have its explanation in anthropogenic fires caused by Mesolithic groups visiting the area. Later, this activity influenced the increase of erosion (e.g., expressed in high sedimentation rate) and, consequently, the increase of turbidity and fertility in the lakeshore which, finally, affected aquatic invertebrate assemblages. After that, a temporary increase in lake water transparency took place, which can be defined as a mesotrophic phase of water conditions. Therefore, periods of increased concentration of charred remains are not always simultaneous in time with periods of enhanced erosion and changes in trophic status of the lake (higher lake productivity). Alternatively, these periods may indicate at least two separate activity episodes of Mesolithic groups in the studied area. This hypothesis is confirmed by radiocarbon age determinations $(6,500 \pm 40$ and $5,870 \pm 40 \mathrm{BP})$ for the burnt animal bones found in 2018 in the layers of trench " $n$ " and inside the dwelling structure in 2003 (Bobrowski and Sobkowiak-Tabaka 2016)—see Table 1. The aforementioned results suggest separate settlement episodes (ca 5,500-5,300 вС and сa 4900-4700 вс) rather than permanent occupation of the Kopanica site. 


\section{Conclusions}

Even though the Mesolithic groups in the studied area are relatively well known (Hildebrandt-Radke 2016; Kobusiewicz 2016), there are not many radiocarbon dates from the Late Mesolithic/Early Neolithic archaeological sites from western Poland. Therefore, our results bring some new information about human population before ca 4500 BC. Thus, we are involved in the discussion about the possibility that climate change (temperature rise) in the middle Holocene might have been responsible for the coincidental population increase (Warden et al. 2017). This phenomenon led to cascading effects, such as changes of type of settlement, cultural composition, introduction of farming, increase in the efficiency of the use of the energy capacity of the environment and other mechanisms for the coming neolithisation process (e.g., Kelly 2013; Hamilton et al. 2016).

The results of the combined macroscopic and microscopic botanical analyses allow a more specific interpretation of Mesolithic activities at and near the Kopanica site. The presence of charred remains of herbaceous marsh plants in particular suggests that burning of the local marsh vegetation may have been a common and recurrent practice to maintain access to open water or to improve hunting strategy and/or to increase the yield of edible plants. In addition, such activities of Mesolithic hunter-gatherers could have influenced the relatively strong increase of erosion of the lakeshore, and the increase of fertility in the lake which, finally, affected aquatic invertebrate assemblages.

Acknowledgements This work was supported by the National Science Centre, Poland, Grant 2016/21/B/HS3/03134, awarded to Iwona Sobkowiak-Tabaka. We are grateful to Przemysław Bobrowski (Institute of Archaeology and Ethnology PAS) for his great help during the excavations; Bernadeta Kufel-Diakowska (Institute of Archaeology, Wrocław University) for sharing her unpublished data; Tomasz Karasiewicz, Przemysław Kujawa (Mikołaj Kopernik University, Toruń) and the archaeological team for taking the core of biogenic sediments; Carla Rosenberg for improving our version of the English text.

Open Access This article is distributed under the terms of the Creative Commons Attribution 4.0 International License (http://creativeco mmons.org/licenses/by/4.0/), which permits unrestricted use, distribution, and reproduction in any medium, provided you give appropriate credit to the original author(s) and the source, provide a link to the Creative Commons license, and indicate if changes were made.

\section{References}

Battarbee RW (1986) Diatom analysis. In: Berglund BE (ed) Handbook of holocene palaeoecology and palaeohydrology. Wiley, Chichester, pp 527-570

Bednarek R, Prusinkiewicz Z (1997) Geografia gleb. Państwowe Wydawnictwo Naukowe, Warszawa
Behre KE (ed) (1986) Anthropogenic indicators in pollen diagrams. Balkema, Rotterdam

Berglund BE, Ralska-Jasiewiczowa M (1986) Pollen analysis. In: Berglund BE (ed) Handbook of Holocene palaeoecology and palaeohydrology. Wiley, Chichester, pp 455-483

Beug H-J (2004) Letfaden der Pollenbestimmung für Mitteleuropa und angrenzende Gebiete. Pfeil, München

Bjerring R, Becares E, Declerck S, Gross EM, Hansson L-A, Kairesalo T, Nykanen M, Halkiewicz A, Kornijów R, Conde-Porcuna JM, Seferlis M, Noges T, Moss B, Amsinck SL, Vad Odgaard B, Jeppesen E (2009) Subfossil Cladocera in relation to contemporary environmental variables in 54 Pan-European lakes. Freshw Biol 54:2,401-2,417. https://doi.org/10.1111/j.1365-2427.2009.02252.x

Bobrowski P, Sobkowiak-Tabaka I (2016) Osadnictwo późnomeozolityczne na stanowisku 29 w Kopanicy, gm. Siedlec. Folia Praehist Posnaniensia 2:9-34. https://doi.org/10.14746/ fpp.2016.21.01

Denys L (1991) A check-list of the diatoms in the Holocene deposits of the western Belgian coastal plan with a survey of their apparent ecological requirements. I: Introduction, ecological code and complete list. Belgische Geologische Dienst, Professional Paper 1991/2-No 246. Ministerie van Economische Zaken, Berchem

Dietze E, Theuerkauf M, Bloom K et al (2018) Holocene fire activity during low-natural flammability periods reveals scale-dependent cultural human-fire relationships in Europe. Quat Sci Rev 201:4456. https://doi.org/10.1016/j.quascirev.2018.10.005

Frey DG (1986) Cladocera analysis. In: Berglund BE (ed) Handbook of Holocene paleoecology and paleohydrology. Wiley, Chichester, pp 667-692

Goslar T, van der Knaap WO, Kamenik Ch, van Leeuwen JFN (2009) Free-shape $14 \mathrm{C}$ age-depth modelling of an intensively dated modern peat profile. J Quat Sci 24:481-499. https://doi.org/10.1002/ jqs. 1283

Granoszewski W, Krupiński KM, Nita M, Nalepka D (2004a) Hedera helix L.-Ivy. In: Ralska-Jasiewiczowa M, Latałowa M, Wasylikowa K, Tobolski K, Madeyska E, Wright HE Jr, Turner C (eds) Late Glacial and Holocene history of vegetation in Poland based on isopollen maps. W. Szafer Institute of Botany, Polish Academy of Sciences, Kraków, pp 111-117

Granoszewski W, Nita M, Nalepka D (2004b) Viscum album L.-Mistletoe. In: Ralska-Jasiewiczowa M, Latałowa M, Wasylikowa K, Tobolski K, Madeyska E, Wright HE Jr, Turner C (eds) Late Glacial and Holocene history of vegetation in Poland based on isopollen maps. W. Szafer Institute of Botany, Polish Academy of Sciences, Kraków, pp 237-243

Grimm EC (1992) Tilia and Tilia-Graph. Pollen Spreadsheet and Graphics Programs. In: Pons A (ed) 8th International Palynological Congress: Program and Abstracts 56, Aix-en-Provence, September 6-12, 1992. Elsevier, Amsterdam, New York

Hamilton MJ, Lobo J, Rupley H, West GB (2016) The ecological and evolutionary energetics of hunter-gatherer residential mobility arxiv:1602.00631 [physics.soc-ph]

Hather JG (1998) Identification of macroscopic charcoal assemblages. In: Mellars P, Dark P (eds) Star Carr in context: new archaeological and palaeoecological investigations at the Early Mesolithic site of Star Carr in North Yorkshire. McDonald Institute of Archaeological Research, Cambridge, pp 183-196

Heiri O, Lotter AF, Lemcke G (2001) Loss on ignition as a method for estimating organic and carbonate content in sediments: reproducibility and comparability of results. J Paleolimnol 25:101-110. https://doi.org/10.1023/A:1008119611481

Hildebrandt-Radke I (2016) Analiza przestrzenna środowiskowych uwarunkowań lokalizacji osadnictwa w regionie Wojnowa $\mathrm{z}$ wykorzystaniem GIS. In: Kobusiewicz M (ed) Region Wojnowo. Arkadia łowców i zbieraczy. Ośrodek Studiów Pradziejowych i Średniowiecznych Instytut Archeologii i Etnologii Polskiej 
Akademii Nauk, Poznań, pp 75-92. http://www.iaepan.poznan.pl/ iaepan01/images/PDF/Region-Wojnowo.-Arkadia-owcw-i-zbier aczy-2a.pdf. Accessed 5 Dec 2016

Huntley B, Birks HJB (1983) An atlas of past and present pollen maps for Europe: 0-13000 years ago. Cambridge University Press, Cambridge

Hustedt F (1939) Die Diatomeenflora des Küstengebiets der Nordsee vom Dollart bis zur Elbmündung. Abh Naturwiss Ver Bremen 31:571-677

Innes JB, Blackford J (2003) The ecology of late mesolithic woodland disturbances: model testing with fungal spore assemblage data. $\mathrm{J}$ Archaeol Sci 30:185-194

Innes JB, Blackford JJ, Rowley-Conwy PA (2013) Late Mesolithic and early Neolithic forest disturbance: a high resolution palaeoecological test of human impact hypotheses. Quat Sci Rev 77:80-100. https://doi.org/10.1016/j.quascirev.2013.07.012

Iversen J (1944) Viscum, Hedera and Ilex as climate indicators. Geol Fören Stockholm För 66:463-483

Jones RL, Keen DH (1993) The flandrian temperate stage. In: Jones RL, Keen DH (eds) Pleistocene environments in the British isles. Springer, Dordrecht, pp 208-274. https://doi. org/10.1007/978-94-011-1520-9_10

Juggins S (2017) rioja: analysis of quaternary science data, $R$ package version (0.9-15). http://cran.r-project.org/package=rioja

Kelly RL (2013) The lifeways of hunter-gatherers: the foraging spectrum, 2nd edn. Cambridge University Press, Cambridge

Kittel P, Muzolf B, Płóciennik M et al (2014) A multi-proxy reconstruction from Lutomiersk-Koziówki, Central Poland, in the context of early modern hemp and flax processing. J Archaeol Sci 50:318-337

Kobusiewicz M (ed) (2016) Region Wojnowo. Arkadia łowców i zbieraczy. Ośrodek Studiów Pradziejowych i Średniowiecznych Instytut, Archeologii i Etnologii Polskiej Akademii Nauk, Poznań. http://www.iaepan.poznan.pl/iaepan01/images/PDF/ Region-Wojnowo.-Arkadia-owcw-i-zbieraczy-2a.pdf. Accessed 5 Dec 2016

Kolkwitz R, Marrson M (1908) Ökologie der pflanzlichen Saprobien. Ber Dtsch Bot Ges 26a:505-519

Komárek J, Jankovská V (2001) Review of the Green Algal Genus Pediastrum; Implication for Pollenanalytical Research. Bibliotheca Phycologica 108. Cramer, Berlin, Stuttgart, Berlin

Kozłowski JK, Kozłowski SK (1977) Epoka kamienia na ziemiach polskich. Państwowe Wydawnictwo Naukowe, Warszawa

Krammer K (2002) Cymbella. In: Lange-Bertalot H (ed) Diatoms of Europe, vol 3. Gantner, Ruggell

Krammer K, Lange-Bertalot H (1986) Bacillariophyceae 1: naviculaceae. In: Ettl H, Gerloff J, Heynig H, Mollenhauer D (eds) Süsswasserflora von Mitteleuropa vol 2, 1. Fischer, Stuttgart

Krammer K, Lange-Bertalot H (1988) Bacillariophyceae 2: epithemiaceae, bacillariacea, surirellaceae. In: Ettl H, Gerloff J, Heynig H, Mollenhauer D (eds) Süsswasserflora von Mitteleuropa vol 2, 2. Fischer, Stuttgart

Krammer K, Lange-Bertalot H (1991a) Bacillariophyceae: Centrales, Fragilariaceae, Eunotiaceae. In: Ettl H, Gerloff J, Heynig H, Mollenhauer D (eds) Süsswasserflora von Mitteleuropa Vol 2, 3. Fischer, Stuttgart

Krammer K, Lange-Bertalot H (1991b) Bacillariophyceae 4: achnanthacea. In: Ettl H, Gerloff J, Heynig H, Mollenhauer D (eds) Süsswasserflora von Mitteleuropa Vol 2, 4. Fischer, Stuttgart

Krygowski B (1972) Wielkopolska Lowland. In: Galon R (ed) Geomorphology of Poland, part 2: Polish Lowland. Państwowe Wydawnictwo Naukowe, Warszawa, pp 186-223

Kubiak-Martens L (2016) Local vegetation and human presence in the Wojnowo Region during the Younger Dryas and Early Holocene. In: Kobusiewicz M (ed) Region Wojnowo. Arkadia łowców i zbieraczy. Ośrodek Studiów Pradziejowych i Średniowiecznych
Instytut, Archeologii i Etnologii Polskiej Akademii Nauk, Poznań, pp 59-74. http://www.iaepan.poznan.pl/iaepan01/images/PDF/ Region-Wojnowo--Arkadia-owcw-i-zbieraczy-2a.pdf. Accessed 5 Dec 2016

Kubiak-Martens L, Tobolski K (2014) Late pleistocene and early holocene vegetation history and use of plant foods in the middle Vistula river valley at Całowanie. In: Schild $\mathrm{R}$ (ed) Całowanie: a final Paleolithic and Early Mesolithic site on an island in the ancient Vistula Chanel. Institute of Archaeology and Ethnology Polish Academy of Sciences, Warsaw, pp 333-348

Kubiak-Martens L, Verbruggen F, Kooistra LI (2015) Archaeobotany: landscape reconstruction and plant food subsistence economy on a meso and microscale. In: Moree JM, Sier MM (eds) Interdisciplinary Archaeological Research Programme Maasvlakte-2, Rotterdam, Part 1: Twenty metres deep! The Mesolithic period at the Yangtze Harbour site - Rotterdam Maasvlakte, the Netherlands. Early Holocene landscape development and habitation. BOORrapporten 566. Bureau Oudheidkundig Onderzoek Rotterdam, Rotterdam, pp 223-286

Kupryjanowicz M, Filbrandt-Czaja A, Noryśkiewicz AM, Noryskiewicz B, Nalepka D (2004) Tilia L.-Lime. In: Ralska-Jasiewiczowa M, Latałowa M, Wasylikowa K, Tobolski K, Madeyska E, Wright HE Jr, Turner C (eds) Late Glacial and Holocene history of vegetation in Poland based on isopollen maps. W. Szafer Institute of Botany, Polish Academy of Sciences, Kraków, pp $217-224$

Latałowa M (1992) Man and vegetation in the pollen diagrams from Wolin Island (NW Poland). Acta Palaeobot 32:123-149

Law C (1998) The uses and fire-ecology of reedswamp vegetation. In: Mellars P, Dark P (eds) Star carr in context: new archaeological and palaeoecological investigations at the early mesolithic site of Star Carr, North Yorkshire. McDonald Institute of Archaeological Research, Cambridge, pp 197-206

Mellars P (1976) Fire ecology, animal populations and man: a study of some ecological relationships in prehistory. Proc Prehist Soc 42:15-45

Mortensen MF, Henriksen PS, Bennike O (2014a) Living on the good soil: relationships between soils, vegetations and human settlement during the late Allerød period in Denmark. Veget Hist Archaeobot 23:195-205

Mortensen MF, Henriksen PS, Christensen Ch, Petersen PV, Olsen J (2014b) Late Glacial and Early Holocene vegetation development in southeast Denmark-Palaeoenvironmental studies from a small lake basin close to the Palaeolithic sites of Hasselø. In: Gulløv HCh (ed) Northern worlds-landscapes, interactions and dynamics. Studies in Archaeology and History 22. The National Museum of Denmark, Copenhagen, pp 169-188

Multan M (2003) Detailed Geological Map of Poland 1:50 000. Sheet: Kargowa (539). Państwowy Instytut Geologiczny, Warszawa

Naumann E (1932) Grundzüge der regionalen Limnologie. Die Binnengewässer Bd. 11. Schweizerbart'sche Verlagsbuchhandlung, Stuttgart

Nevalainen L (2011) Intra-lake heterogeneity of sedimentary cladoceran (Crustacea) assemblages forced by local hydrology. Hydrobiologia 676:9-22. https://doi.org/10.1007/s10750-011-0707-3

Nevalainen L, Luoto TP, Kultti S, Sarmaja-Korjonen K (2012) Do subfossil Cladocera and chydorid ephippia disentangle Holocene climate trends? Holocene 22:291-299. https://doi.org/10.1177/09596 83611423691

Okuniewska-Nowaczyk (2016) Rejon Wojnowa w świetle badań palinologicznych. In: Kobusiewicz M (ed) Region Wojnowo. Arkadia łowców i zbieraczy. Ośrodek Studiów Pradziejowych i Średniowiecznych Instytut, Archeologii i Etnologii Polskiej Akademii Nauk, Poznań, pp 39-57. http://www.iaepan.poznan.pl/ iaepan01/images/PDF/Region-Wojnowo.-Arkadia-owcw-i-zbier aczy-2a.pdf. Accessed 5 Dec 2016 
Osipowicz G (2019) Plant processing in the Late Mesolithic Poland: in search for function of the mysterious 'curved knives'. Archaeol Anthropol Sci 11:3,613-3,628. https://doi.org/10.1007/s1252 0-019-00784-w

Pawłowski D (2011) Evolution of an Eemian lake based on Cladocera analysis (Konin area, Central Poland). Acta Geol Pol 61:441-450

Pawłowski D (2017) The usefulness of subfossil Cladocera remains in Younger Dryas climatic reconstructions in central Poland. Acta Geol Pol 67:567-584

Pawłowski D, Gruszka B, Gallas H, Petera-Zganiacz J (2013) Changes in the biota and sediments of glacial Lake Koźmin, Poland, during the late Saalian (Illinoian). J Paleolimnol 49:679-696. https://doi. org/10.1007/s10933-013-9692-z

Pawłowski D, Milecka K, Kittel P, Woszczyk M, Spychalski W (2015) Palaeoecological record of natural changes and human impact in a small river valley in Central Poland. Quat Int 370:12-28. https ://doi.org/10.1016/j.quaint.2014.06.033

Pawłowski D, Borówka RK, Kowalewski G et al (2016a) The response of flood-plain ecosystems to the Late Glacial and Early Holocene hydrological changes: a case study from a small Central European river valley. CATENA 147:411-428. https://doi.org/10.1016/j. catena.2016.07.034

Pawłowski D, Borówka RK, Kowalewski GA et al (2016b) Late Weichselian and Holocene record of the paleoenvironmental changes in a small river valley in Central Poland. Quat Sci Rev 135:24-40. https://doi.org/10.1016/j.quascirev.2016.01.005

Ralska-Jasiewiczowa M, van Geel B (1998) Human impact on the vegetation of the Lake Gościąż surroundings in prehistoric and earlyhistoric times. In: Ralska-Jasiewiczowa M, Goslar T, Madeyska T, Starkel L (eds) Lake Gościąż, Central Poland. W. Szafer Institute of Botany, Kraków, pp 267-294

Ralska-Jasiewiczowa M, Latałowa M, Tobolski K, Madeyska E, Wright HE Jr, Turner C (2004) Late Glacial and Holocene history of vegetation in Poland based on isopollen Maps. W. Szafer Institute of Botany, Polish Academy of Sciences, Kraków

Ramsey CB (2009) Dealing with outliers and offsets in radiocarbon dating. Radiocarbon 51:1,023-1,045. https://doi.org/10.2458/ azu_js_rc.51.3561

Reimer PJ, Bard E, Bayliss A et al (2013) IntCal13 and Marine13 radiocarbon age calibration curves $0-50,000 \mathrm{cal} \mathrm{BP}$. Radiocarbon 55:1,869-1,887. https://doi.org/10.2458/azu_js_rc.55.16947

Round FE (1981) The biology of algae. Cambridge University Press, Cambridge

Schlanger SH (1992) Recognizing persistent places in Anasazi settlement systems. In: Rossignol J, Wandsnider L (eds) Space, time and archaeological landscapes. Plenum Press, New York, pp 91-112

Schrader H-J, Gersonde R (1978) Diatoms and silicoflagellates. Utrecht Micropaleontol Bull 17:129-176

Sergant J, Crombé P, Perdaen Y (2006) The 'invisible' hearths: a contribution to the discernment of Mesolithic non-structured surface hearths. J Archaeol Sci 33(999-1):007. https://doi.org/10.1016/j. jas.2005.11.011

Sobkowiak-Tabaka I, Kufel-Diakowska B (2019) The shining piece of puzzle: evidence of plant use in the Late Palaeolithic. Archaeol Anthropol Sci 11:1,373-1,389. https://doi.org/10.1007/s1252 0-018-0604-z

Sobkowiak-Tabaka I, Kubiak-Martens L, Okuniewska-Nowaczyk I, Kurzawska A, Ratajczak-Szczerba M, Kufel-Diakowska B (2018) Reconstruction of the late glacial and early holocene landscape and human presence on the basis of multidisciplinary analyses from Lubrza in Western Poland. Environ Archaeol 23:123-136. https://doi.org/10.1080/14614103.2016.1268993

Środoń A (1991) Lipa w minionych krajobrazach Polski. In: Bugała W (ed) Lipy: Tilia cordata Mill. Tilia platyphyllos Scop. Nasze drzewa leśne 15. Instytut Dendrologii PAN, Kórnik, Poznań, pp 9-19

Stahlschmidt MC, Miller CE, Ligouis B et al (2015) On the evidence for human use and control of fire at Schöningen. J Hum Evol 89:181-201. https://doi.org/10.1016/j.jhevol.2015.04.004

Szczepanek K, Tobolski K, Nalepka D (2004) Alnus Mill. - Alder. In: Ralska-Jasiewiczowa M, Latałowa M, Wasylikowa K, Tobolski K, Madeyska E, Wright HE, Turner C (eds) Late glacial and holocene history of vegetation in Poland based on isopollen maps. W Szafer Institute of Botany, Polish Academy of Sciences, Kraków, pp 47-55

Szeroczyńska K (2002) Human impact on lakes recorded in the remains of Cladocera (Crustacea). Quat Int 95-96:165-174

Szeroczyńska K, Sarmaja-Korjonen K (2007) Atlas of subfossil Cladocera from central and northern Europe. Friends of Lower Vistula Society, Swiecie, pp 1-87

Taylor B, Conneller C, Milner N, Elliott B, Little A, Knight B, Bamforth M (2018) Human lifeways. In: Milner N, Conneller C, Taylor B (eds) Star Carr, vol 1. A Persistent Place In A Changing World. White Rose University Press, York, pp 245-272

Tobolski K, Nalepka D (2004) Fraxinus excelsior L. - Ash. In: RalskaJasiewiczowa M, Latałowa M, Wasylikowa K, Tobolski K, Madeyska E, Wright HE Jr, Turner C (eds) Late Glacial and Holocene history of vegetation in Poland based on isopollen maps. W. Szafer Institute of Botany, Polish Academy of Sciences, Kraków, pp 105-110

Tóth M, van Hardenbroek M, Bleicher N, Heiri O (2019) Pronounced early human impact on lakeshore environments documented by aquatic invertebrate remains in waterlogged Neolithic settlement deposits. Quat Sci Rev 205:126-142. https://doi.org/10.1016/j. quascirev.2018.12.015

Turner F, Tolksdor JF, Viehberg F et al (2013) Lateglacial/Early Holocene fluvial reactions of the Jeetzel River (Elbe Valley, Northern Germany) to abrupt climatic and environmental changes. Quat Sci Rev 60:90-109. https://doi.org/10.1016/j.quascirev.2012.10.037

Van Geel B, Aptroot A (2006) Fossil ascomycetes in Quaternary deposits. Nova Hedwigia 82:313-329. https://doi. org/10.1127/0029-5035/2006/0082-0313

Vanmontfort B, van Gils M, Paulissen E, Bastiaens J, De Bie M, Meirsman E (2010) Human occupation of the late and early post-glacial environments in the liereman landscape (Campine, Belgium). J Archaeol Low Ctries 2:31-51

Warden L, Moros M, Neumann T et al (2017) Climate induced human demographic and cultural change in northern Europe during the mid-Holocene. Sci Rep 7:15,251. https://doi.org/10.1038/s4159 8-017-14353-5

Whiteside MC (1970) Danish Cladocera: modern ecology and core studies. Ecol Monogr 40:79-118

Zagwijn WH (1994) Reconstruction of climate change during the Holocene in western and central Europe based on pollen records of indicator species. Veg Hist Archaeobot 3:65-88

Zohary D, Hopf M (1988) Domestication of plants in the old world. The origin and spread of cultivated plants in West Asia, Europe, and the Nile valley. Clarendon Press, Oxford

Publisher's Note Springer Nature remains neutral with regard to jurisdictional claims in published maps and institutional affiliations. 